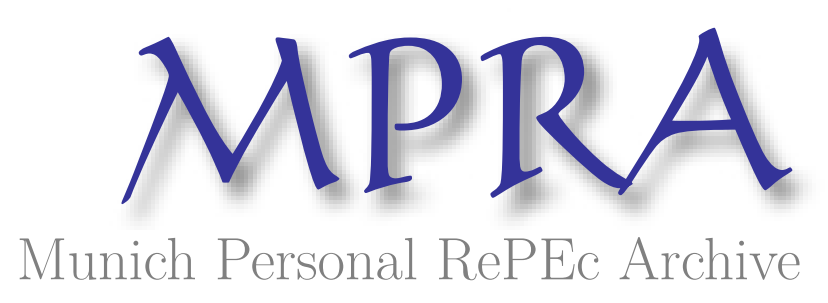

\title{
Obesity and labor market in Peru
}

Nuñez, Roy

Universidad de las Americas Puebla

1 July 2020

Online at https://mpra.ub.uni-muenchen.de/105621/

MPRA Paper No. 105621, posted 01 Feb 2021 10:12 UTC 


\title{
Obesity and labor market in Peru
}

\author{
Roy Nuñez \\ Department of Economics \\ Universidad de las Américas Puebla
}

This version: July 2020

\begin{abstract}
Obesity is a problem that affects not only developing countries, but also middle-income countries. Using anthropometric and socioeconomic information, I analyzed the relationship between obesity and employment and wages in Peru, a country that has shown rapid economic growth in the last decade. The results show that an increase in the body mass index (BMI) has a negative relationship with the probability of women working $(-0.3$ percentage points, on average), particularly among married women and those living in urban areas. In the case of men, no statistically significant relationship is observed. Regarding monthly wages, an increase in BMI is associated with a $0.8 \%$ reduction in women's wages (US\$ 2.3, on average). This effect is seen in the upper part of the wages distribution and among those who are in the BMI obesity range. In the case of men, the effect is positive and significant (additional US\$ 4.5, on average) in most of the subgroups analyzed. These results are similar to those observed in the international literature.
\end{abstract}

Key words: obesity; labor market; Peru.

JEL Codes: I15; I12; J21; J30.

- Email: roy.nunez@udlap.mx. Tel.: +55-222-229-2616. Universidad de las Americas Puebla, Departament of Economics, Ex Hacienda Sta. Catarina Martir S/N. San Andres Cholula, Puebla. 72810. Mexico. 


\section{Introduction}

Peru is a middle-income country that, in recent decades, has shown growth rates of around $4 \%$ (BCRP, 2018). This fact has been reflected both in better living conditions for its inhabitants and in employment levels (INEI, 2019). However, some issues pending to be resolved are the improvement of the health system and policies that promote welfare among its workers (Revilla et al., 2012; Schwalb et al., 2014). In this regard, little has been studied in the country about the possible relationship between having a workforce with health problems - such as obesity - with employment and wages.

According to the World Health Organization and the Organization for Economic Cooperation and Development, obesity is one of the great ills of this age, since it is the trigger for many diseases such as diabetes mellitus and hypertension (WHO, 2018; OECD, 2019); being a problem that not only afflicts high-income countries but also developing countries. In the case of Peru, Álvarez-Dongo et al. (2012) show that not being poor and living in urban areas are some of the social determinants of being overweight. Similarly, according to data from the National Institute of Health of Peru, between 2007 and 2011, 11.8\% of men and 19.6\% of women between 15 and 65 years suffered from obesity; that is, they had a Body Mass Index (BMI) above 30; $40.2 \%$ of men and $38.1 \%$ of women were overweight (BMI between 25 and 30); while $48 \%$ and $42.3 \%$ of men and women, respectively, were in the normal range (BMI between 20 and 25).

The relationship between obesity and the labor market can occur in various ways. At the macroeconomic level, as we have a workforce with greater health problems - such as obesity public spending in this area will increase. In this regard, studies by Cawley and Meyerhoefer (2012) and Thompson et al. (1999) for the United States show that obesity is related to an increase in medical expenses; in the case of Cawley and Meyerhoefer (2012), this expense amounts to US\$ 3,000, on average, per person per year. Similarly, changes in the work environment, such as the change from manual activities to automated activities, can lead to a sedentary lifestyle at work and therefore to obesity problems (Philipson and Posner, 1999; Lakdawalla and Philipson, 2002; Ehmke et al., 2008). 
At the microeconomic level, obesity may be associated with a greater absence due to illness (Bramming et al., 2019), lower productivity and, therefore, lower wages. However, this result is more complex, as there are unobservable factors that determine whether a person (or an employer) decides to offer (or hire) labor. Thus, for example, workers may or may not self-select to work according to their preferences or attributes (Gortmaker et al., 1993; Loh, 1993; Mitra, 2001; DeBeaumont and Girtz, 2019), while employers may place restrictions on hiring according to their preferences related to physical appearance (Agerström and Rooth, 2011; Caliendo and Lee, 2013; Galarza and Yamada, 2014; Arceo-Gomez and Campos-Vazquez, 2014; CamposVazquez and Gonzalez, 2020). In either case, failure to take these variables into consideration may lead to erroneous results.

Much of the previous literature is based on developed countries, where the evidence shows negative effects on both income and employment (Averett, 2019). By sex, the majority of results in the European Union show a reduction in women's employment (Morris, 2007; Greve, 2008; Johansson et al., 2009; Han et al., 2009; Asgeirsdottir, 2011; Caliendo and Gehrsitz, 2016). Only in the cases of the United States and England are there negative effects on men's employment, while in Germany the result is positive. In the case of China, Jay and Xuezheng (2013) find that both men and women are discriminated from the labor market due to their physical appearance. Finally, Carrillo et al. (2017) and Clément et al. (2020) find positive effects on employment in Brazil and Mexico.

With regard to wages, results for Europe and China show negative effects on men and women (Brunello and d'Hombres, 2005; Cawley et al., 2005; Garcia and Quintana-Domeque, 2006; Brunello and d'Hombres, 2007; Atella et al., 2008; Shimokawa, 2008; Garcia and QuintanaDomeque, 2009; Lundborg et al., 2010; Bozoyan and Wolbring, 2011; Lundborg et al., 2014; Caliendo and Gehrsitz, 2016; Clément et al., 2020); for the United States, evidence of negative effects is only found in women (Register and Williams, 1990; Pagan and Davila, 1997; Averett and Korenman, 1999; Baum and Ford, 2004; Cawley, 2004; Cawley et al., 2005; DeBeaumont , 2009; Han et al., 2009; Mocan and Tekin, 2011; Han et al., 2011; Sabia and Rees, 2012; Johar and Katayama, 2012), while Cawley (2000), Pinkston (2017) and Wada and Tekin (2010) found no effects. For developing countries, the results are mixed. Carrillo et al. (2017), Colchero and 
Bishai (2012), Ahsan and Böckerman (2019) and Clément et al. (2020), find positive effects for Brazil, the Philippines, Indonesia and Mexico (only men); while Campos-Vazquez and Nuñez (2019) find negative effects for women in Mexico.

Regarding the identification strategy, and as previously mentioned, the presence of unobservable variables that affect both employment and wages decisions and obesity prevent recovering the causal effect of obesity on the labor market. Various authors suggest the use of instrumental variables as a way of dealing with this problem (Cawley, 2000, 2004; Brunello and d'Hombres, 2005; Cawley et al., 2005; Morris, 2006; Atella et al., 2008; Shimokawa , 2008; Lindeboom et al., 2009; Kortt and Leigh, 2010; Wada and Tekin, 2010; Johar and Katayama, 2012; Sabia and Rees, 2012; Campos-Vazquez and Nuñez, 2019). In most cases, BMI of the children is used as an instrument (genetic relationship) since it is expected to be unrelated to the parents' work decisions. However, the use of genetic relationships as instruments has recently been criticized (Conley, 2009; Benjamin et al., 2011; Cawley et al., 2011), since it is not possible to ensure that the instrument meets the exclusion condition necessary for the instrument to be valid.

In this sense, the present study seeks to show evidence of the relationship between obesity and employment and wages in a middle-income country like Peru, leaving the causal issue for future research. I consider the case of Peru as important insofar as in recent years it has shown a considerable improvement in its economic indicators; however, it still presents difficulties to transfer this improvement in the well-being of its population. I used the National Household Survey (ENAHO-CENAN) for the rounds: 2007-2008, 2009-2010 and 2011, since it has socioeconomic information such as anthropometric information of the population. It is important to mention that, in order to avoid bias in the measurement of BMI, the survey allows us to know the weight of the respondents net of the garments used. The results show that, in the case of employment, an increase in one unit of BMI has a negative relationship with the probability of working for women (-0.3 percentage points, on average) and no statistically significant relationship in men. In the case of monthly wages, a positive relationship is seen for men (1.3\%) and a negative one for women $(-0.8 \%)$. These values are similar to those found in the international literature. The rest of the document consists of six parts: a brief review of the earlier 
literature, descriptive statistics, the identification strategy followed, the main results, the results in subgroups and the conclusions.

\section{Previous literature}

Most of the literature on obesity and its relation to employment and wages is concentrated in developed countries, one of the main concerns in the analysis being the possible bias resulting from the presence of unobservable variables in the model. In this regard, various econometric techniques seek to recover the causal effect of obesity on employment and wages. Thus, the success in this process lies in the assumptions that are being made. Despite this, the results in general indicate that this disease has a negative impact on the labor market.

In principle, if the model to be estimated did not depend on unobservable variables, the use of ordinary least squares (OLS) would be sufficient to recover the causal effect of obesity on employment and wages. Examples of this are the works of Greve (2008), Morris (2007), Johansson et al. (2009), Caliendo and Gehrsitz (2016), Asgeirsdottir (2011) and Han et al. (2009), who, for the cases of Denmark, England, Finland, Germany, Iceland and the United States, respectively, find evidence of a negative effect of the increase in BMI on the probability of women working. In the case of men, the results are mixed and, in the case of some of these countries, they are non-significant. The cases of the United States and England stand out, where obesity is negatively related to employment, while the opposite result is observed in Germany. ${ }^{1}$

The application of this technique in the case of wages and income shows a similar result, the negative effects being concentrated mainly on women. In the case of the United States, Cawley (2000), Cawley (2004), Cawley et al. (2005), Han et al. (2011), Johar and Katayama (2012), Mocan and Tekin (2011), Pagan and Davila (1997) and Sabia and Rees (2012) found that the increase in BMI is associated with a reduction between $0.2 \%$ and $1.8 \%$ in hourly wages. In the case of Europe, Brunello and d'Hombres (2005, 2007), Caliendo and Gehrsitz (2016), and Garcia and Quintana-Domeque (2006) observed a wages penalty between $0.1 \%$ and $1 \%$. For men,

\footnotetext{
${ }^{1}$ An alternative strategy to this method is to use a semi-parametric analysis, as observed in Hildebrand and Van Kerm (2010) and Caliendo and Gehrsitz (2016).
} 
results are mixed: Cawley (2004), Johar and Katayama (2012), and Pagan and Davila (1997) found negative effects in white men with obesity (between $0.2 \%$ and $1 \%$ ), while Sabia and Rees (2012) found positive effects.

An alternative method to recover the causal effect is by applying matching techniques; that is, finding groups of individuals with similar observable characteristics, where the only difference is the presence or not of obesity. Morris (2007) applied this technique to the case of England and found that obesity reduces the probability of being employed by men and women. Although this technique allows the causal effect to be recovered, it presents the same initial problem, since it does not correct the selection in unobservable variables, so the bias remains.

If the unobservable characteristics are invariant over time, an alternative strategy is to use models with fixed effects. An example of this is found in the works of Brunello and d'Hombres (2005, 2007), Lundborg et al. (2010, 2014), Han et al. (2009, 2011), Pinkston (2017), Baum and Ford (2004), Ahn et al. (2019), for the United States, England and South Korea. Their results show a reduction in women's income as obesity increases. However, the application of this technique requires that the variable under study - BMI - presents sufficient variation between periods, as well as a considerable sample of individuals.

Finally, it is important to mention the generalized use of instrumental variables as a mechanism to recover the causal effect of obesity on the labor market. In principle, the use of instrumental variables requires compliance with the conditions of exogeneity and relevance of the instrument; that is, it should not be correlated with unobservable characteristics that may affect the variable of interest (in our case, those linked to the labor market), while, at the same time, it must be related to the explanatory variable (in our case, with BMI). The literature considers two possible instruments: those linked to the literature on genetics and economics and those linked to the environment of people.

As for the genetic components, Dolton and Xiao (2015), Locke et al. (2015), Herrera et al. (2011), Savona-Ventura and Savona-Ventura (2015), Biroli (2015), Cawley et al. (2017) and Brunello et al. (2019) consider that part of obesity is transmitted through this route, so the 
presence of parents or family members with obesity makes children more likely to suffer from it. In this sense, Atella et al. (2008), Brunello and d'Hombres (2005, 2007), Norton and Han (2008), Kortt and Leigh (2010), Lindeboom et al. (2009), Cawley et al. (2005), Cawley (2000, 2004), Shimokawa (2008), von Hinke Kessler Scholder et al. (2010), Gregory and Ruhm (2011), Johar and Katayama (2012), Wada and Tekin (2010), Sabia and Rees (2012), Campos-Vazquez and Nuñez (2019), Howe et al. (2019) and Clément et al. (2020) use BMI of a family member or a child as an explanatory variable for the obesity in the working individual. Their results show negative effects mainly on women's income and wages. However, in the genetic relationship of obesity, it is not clear if the obesity of a family member meets the exclusion condition; that is, it does affect work decisions or not. ${ }^{2}$ Authors like Benjamin et al. (2012), Cawley et al. (2011) and Conley (2009) have shown that the current knowledge of genetics and its uses in the social sciences is debatable, as there is not enough knowledge to know if the genes related to obesity are not related to other components which are in turn related to the employment and productivity of people.

On the other hand, instruments related to the environment consider that the environment in which people develop has effects on their eating habits and customs. In this sense, Morris $(2006,2007)$ uses BMI of individuals who are living in the same area of influence of a health care center in England. His results show negative effects on the employment of men and women. However, criticism about the instrument remains, considering that, if people share common characteristics with their environment (such as eating and health habits), it is to be expected that they also have a relationship to their preferences for work, thus invalidating the proposed instrument.

In light of the above, the fact of proposing the use of any of these techniques to recover the causal effect of obesity on employment and wages may lead to erroneous results, in the sense that there are unobservable variables that affect both obesity and employment and wages. In that sense, the present work tries to approximate the relationship between obesity and employment and salaries in Peru, avoiding proposing causal relationships. Although a causal relationship allows us to determine the impact of a phenomenon under study, we consider that this first approach to the Peruvian case is important, in the sense that it gives indications of the effects of this condition

\footnotetext{
${ }^{2}$ See Beauchamp et al. (2011), for the use of genetic data in economics.
} 
among workers, helping in the implementation of health policies. Similarly, we consider the Peruvian case to be interesting in that it is a middle-income country with rapid economic growth in the last decade but still requiring public policies that transfer these macroeconomic results to its citizens.

\section{Descriptive statistics}

Figure 1 shows the population between 15 and 65 years old in Peru according to sex and BMI ranges. This information was obtained based on the ENAHO-CENAN survey for the years 2007 to 2011, which has representation at the national level, urban and rural areas of the country. The survey takes anthropometric measurements for all household members and the abdominal girth for those of 14 years of age and older, as well as information on hemoglobin and physical activity. This information is supplemented by socioeconomic data on household members. ${ }^{3}$

In general, it can be seen that, in the case of men, $48 \%$ are in the normal range, while $42 \%$ of women are in this category. In relation to the overweight population, $40 \%$ of men and $38 \%$ of women are in this condition. Finally, $12 \%$ of men suffer from obesity, while the same situation is seen in $20 \%$ of women. As BMI increases, the proportion of the population that is overweight and obese decreases; however, it is interesting to note that this problem is mainly concentrated among women.

[Insert Figure 1 over here.]

Figure 2 shows the participation in labor market and wages of men and women at different ranges of BMI. The figure on the left shows that, while the percentage of men working is higher as compared to women, both behave differently as BMI increases. Among men, the percentage increases until reaching the overweight range (BMI between 25 and 30), and then slowly declines in the obesity range (BMI > 30). Among women, labor participation only increases in the normal range (BMI between 20 and 25), then declines rapidly as they gain weight. Additionally, it is

\footnotetext{
${ }^{3}$ See INEI (2011).
} 
interesting to note that, while the difference in labor participation between men and women is 5 percentage points in the normal BMI range, it is 15 percentage points in the obesity range.

Regarding wages, the figure on the right shows the evolution of monthly wages (in logarithms) at different ranges of BMI. Women's salaries are higher at the beginning, and then grow at a slower rate than men's, until reaching a maximum in the overweight range. Thus, between the normal range and overweight range, the income of women increases by $10 \%$, while for men the increase is $40 \%$. Similarly, while women's wages decrease as they move from overweight to obesity, men's wages do not decrease. In general, in the obesity range, men's wages are $22 \%$ more than in the case of women.

[Insert Figure 2 over here.]

Table 1 presents the main descriptive statistics obtained with the ENAHO-CENAN for the 20072008, 2009-2010 and 2011 rounds. In general, for the period 2007-2011, we have 45,172 people between 15 and 65 years of age who can work and have information on BMI. Out of this total, those who have a valid income (29.7\%) are considered as workers. In this regard, it is important to mention that the study did not consider pregnant women, as well as those with a BMI that was not between 15 and 45, in order to make the results comparable with other studies. ${ }^{4}$ Column (1) shows that BMI is slightly higher for women (26.3), as compared to men; however, when the sample is restricted to only those who work, BMI for men and women is similar. According to obesity ranges, it is interesting to note that, in the case of those who work, the highest proportion of men are overweight (45.6\%), while in the case of women the proportions are similar to those in column (1).

With respect to characteristics of the sample such as age, marital status, area of residence and speaking indigenous language, we observe that the average age of the sample is 38 years, which drops to 36 when only those who work are taken into consideration. Similarly, the percentages

\footnotetext{
${ }^{4}$ For more details about the restrictions in the sample used, see Table 2. It is common to exclude pregnant women in literature, considering that their body composition and weight are affected by pregnancy (Cawley, 2004; Atella et al., 2008; Wada and Tekin, 2010).
} 
of married people, people living in rural areas and people speaking an indigenous language are lower for both men and women when the sample is limited to those who work. However, the percentage of health problems in the household increases when only the working sample is considered.

Finally, information on education and the labor market shows that the years of schooling for working men increase by 1.3 , while for women the increase is 3.7 years. About participation in the labor market, $43.4 \%$ of men in the sample and $27.6 \%$ of women work, with the number of hours worked per week being higher for men than for women. Similarly, men earn additional 210.5 soles per month, as compared to women (approximately, US\$ 64). In relation to those who work full time, as well as in informal activities, these characteristics are concentrated among men.

[Insert Table 1 over here.]

\section{Identification strategy}

In order to analyze the relationship between obesity and employment and wages, equation (1) was estimated, where $Y_{i}$ is the monthly wage (in logarithms) or a dichotomous variable to indicate whether person $i$ works or not. $B M I_{i}$ is the indicator of obesity and $X_{i}$ is a set of covariates that include age, square age, years of schooling, work experience, square work experience, and dichotomous variables for: area of residence (8 variables), rural area, year of the survey, indigenous language, literacy, marital status, and work formality status. Also included are variables related to the person's health status such as: hypertension, diabetes, coronary artery disease, cancer, alcohol, and tobacco. This equation is estimated by OLS, where the parameter of interest $(\beta)$ measures the association between BMI and labor market. It is important to mention that the results obtained in Figure 2, as well as the application of the RESET test by Ramsey (1969), indicate that the model is non-linear in BMI; therefore, BMI, as well as BMI ranges (normal and underweight: $\mathrm{IMC} \leq 25$; overweight: $25<\mathrm{IMC} \leq 30$; obese > 30), are considered in section 5 together with its square value. Additionally, the correction for selection proposed by Heckman (1979) was made in the estimation of the wage equation. 


$$
Y_{i}=\alpha+\beta * B M I_{i}+\gamma * X_{i}+\mu_{i}
$$

The results presented in equation (1) show the average relationship between BMI and the dependent variable. However, it is possible that this relationship loses much relevant information in the distribution of workers' wages. In other words, the effect of obesity on the population's wages does not have to follow the same pattern among those with low income as it does among those with high income. In this sense, and following Koenker and Bassett Jr (1978), the following equation was estimated:

$$
Q_{\theta}\left(Y_{i} \mid B M I_{i}, X_{i}\right)=\alpha_{\theta}+\beta_{\theta} * B M I_{i}+\gamma_{\theta} * X_{i}
$$

in which the expression on the left shows that the regression is performed on the $\theta$ th quantile of the distribution of the dependent variable. Thus, $\beta_{\theta}$ measures the effect of BMI on wages at different points of the conditional distribution of $Y_{i}$.

\section{Results}

Table 3 shows the results by OLS of the relationship between BMI and employment of men and women. ${ }^{5}$ Panel A makes an estimate similar to equation (1) where it can be seen that in both men and women, BMI is negatively related to the probability of being employed. However, in the case of men, this value is not significant. For women, the increase in BMI by one unit is related to a 0.3 percentage point $(\mathrm{pp})$ reduction in the probability of being employed.

Given the non-linear characteristics discussed in the previous section, panels B and C try to capture these effects. Thus, panel B adds the square of BMI to show the curvature in the regression. The results show that, although there is evidence of a concave shape in the relationship between BMI and employment in both sexes, this is only significant in the case of men. In that sense, BMI has a positive effect on the probability of being employed at the lower end of the distribution of BMI ( $2.9 \mathrm{pp}$ increase), and then having a significant negative effect in

\footnotetext{
${ }^{5}$ For results in detail, see Tables A1, A2 and A3 in the appendix online.
} 
the upper part (-0.1 pp). ${ }^{6}$ Panel $\mathrm{C}$ analyzes the effect of BMI for overweight and obesity ranges relative to the normal range. In the case of men, it is interesting to note that the passage from the normal weight range to overweight has no significant effect on the probability of being employed; however, moving to obesity produces a reduction in the probability of being employed of $4.9 \mathrm{pp}$ with respect to the normal range. For women, the penalty is clearer; both overweight and obesity reduce the probability of employment (-1.4 pp and $-4.3 \mathrm{pp}$, respectively).

These results show that - in the case of Peru - the relationship between obesity and the probability of being employed varies according to sex. In men, the negative effect is only observed in the obesity range of BMI; while in women, the penalty in terms of employment occurs as long as the normal range of $\mathrm{BMI}$ is exceeded. With regard to international literature, results in men are similar to those found by Johansson et al. (2009) and Campos-Vazquez and Nuñez (2019) for Finland and Mexico, where the effect of obesity on employment is negative but not significant. For women, the values obtained are similar to those found by Johansson et al. (2009) in Finland, Caliendo and Gehrsitz (2016) in Germany, Greve (2008) in Denmark, Asgeirsdottir (2011) in Iceland, and Han et al. (2009) for Hispanic women in the United States.

\section{[Insert Table 3 over here.]}

Table 4 shows the relationship between BMI and monthly wages, expressed in logarithms. ${ }^{7}$ Column 1 considers a model similar to that presented in Table 3, while columns 2 and 3 add a previous step by correcting for selection according to the Heckman (1979) criterion. Column 3 incorporates the average age of the children between 6 and 19 living in the household into the selection equation, so the sample is restricted to those workers meeting these characteristics. Panel A shows that, in all cases, BMI is positively related to men's wages and negatively related to women's wages. It should be noted that all the values obtained are statistically significant. In that sense, a one-unit increase in BMI is associated with an increase in men's monthly wages by $1.3 \%$ (US\$ 4.5 in September 2019), while women's monthly wages decrease by $0.8 \%$, i.e., US\$

\footnotetext{
${ }^{6}$ See Figure 2.

${ }^{7}$ See tables A4, A5 and A6 in the appendix online, for complete information about regressions.
} 
2.3 less per month. It is worth mentioning that in columns 2 and 3 Wald test of independence of equations in the selection model is rejected.

Panels B and C try to capture non-linear effects on the relationship of obesity to wages. In the case of panel B, the incorporation of square BMI proves not to be significant in any of the specifications. Panel $\mathrm{C}$ uses dichotomous variables to analyse the effect of BMI according to ranges. In the case of men, we observed that the change from the normal BMI range to the overweight range has a positive relationship to wages ( $4 \%$ increase in monthly wages or US\$ 14.2 , on average, per month). This effect is even greater in the obesity range, where salaries increase between $12 \%$ and $13 \%$ (US\$ 44.2, on average, per month). In contrast, for women, moving from the normal BMI range to overweight is associated with a wage loss of 5\% (US\$ 14.5 ), while there is a loss of about $9 \%$ ( $\$ 26$, on average, per month) in the obesity range. Although signs remain in column 3, results are not significant, which could be explained by the restriction in the sample when incorporating an instrument into the selection equation.

In general, results in wages show a pattern similar to that observed in the case of employment, that is, the increase in BMI is associated with an improvement in men's wages (4.8\% in standard deviations), while a penalty is observed in women which increases as they move away from the normal BMI range (-3.3\% in standard deviations). Among women, the wage reduction due to obesity is comparable to a loss of 0.63 years of schooling, while the result in men is comparable to 1.05 additional years of schooling. In relation to international literature, the values found in men are close to those observed by Lundborg et al. (2014) in the United States for those between 34 and 49 years old, and to those of Garcia and Quintana-Domeque (2009), in the case of Belgium. In particular, the magnitude of the effect is closer to that of Garcia and QuintanaDomeque (2009) (3.9\% in standard deviations). In the case of women, negative effects on wages and hourly wages are found in Han et al. (2011), Han et al. (2009); Cawley et al. (2005); Sabia and Rees (2012); Cawley (2004) for the case of the United States; Brunello and d'Hombres (2005, 2007); Garcia and Quintana-Domeque (2009); Caliendo and Gehrsitz (2016), in the case of Europe, and Campos-Vazquez and Nuñez (2019), in the case of Mexico. The magnitude of the effect found is close to that seen by Garcia and Quintana-Domeque (2009). 
[Insert Table 4 over here.]

Table 5 shows the results of the relationship between BMI and wages according to quantiles. ${ }^{8}$ For men, panel A shows that the positive effect of BMI on monthly wages remains significant and tends to increase when going forward in the distribution of wage income. With regard to the use of BMI and square BMI (panel B), it is observed that the relationship is negative and significant in the 0.15 and 0.5 quantiles, these values being close to zero. Panel $\mathrm{C}$ shows that the positive effect of BMI on men's wages shows different behaviors according to the position in the income distribution. Thus, in the lower quantile, overweight has a positive but not significant relationship to wages, while obesity (with respect to the normal range of BMI) is positively and significantly related. In the upper quantiles, the relationship between BMI and wages is positive and significant as progress is made in the distribution of wage income. For women, panel A shows that the negative relationship between BMI and wages is concentrated at the top of the income distribution. However, it is interesting to note a differentiated behavior in panel $\mathrm{C}$, where overweight is negatively (and significantly) associated only in the lower part of the distribution, while obesity has negative and significant effects in the upper part.

In general, these results show again that obesity would be positively related to men's wages, with this association being stronger as moving to income quantiles. This phenomenon does not seem to be repeated in women, where the wage penalty is concentrated in the upper part of the income distribution and among those located in the obesity range of BMI. It is important to mention that the negative effect found in women may be associated with other unobservable factors, such as appearance, discrimination and social environment, among others (Gortmaker et al., 1993; Loh, 1993; Mitra, 2001; Campos-Vazquez and Gonzalez, 2020). In this sense, although these results offer a sign of a differentiated effect between men and women, a more detailed analysis of these effects on wages and their relationship to obesity is pending for future research.

\section{[Insert Table 5 over here.]}

\footnotetext{
${ }^{8}$ The same procedure was accomplished by selection correction, as proposed by Buchinsky (2002). In all cases, values and signs were similar to those obtained in Table 5, but they were not significant.
} 


\section{Results in subgroups}

Table 6 shows the relationship between BMI and the employment of men and women according to marital status and the area of residence (rural or non-rural). ${ }^{9}$ The second column (married) shows that BMI is negatively and significantly related to the probability of being employed in both men and women (-0.3 pp). According to BMI ranges (panel B), the effect is concentrated in the range of obesity, in the case of men, while the effect is in the range of both overweight and obesity, in the case of women. In relation to singles, the effect is not significant in men, while there is only a negative and significant effect in women within the obesity range of BMI $(-5.3 \mathrm{pp})$.

According to the area of rural or urban residence (columns 4 and 5), it is interesting to note that a positive relationship in the probability of being employed is observed only for men living in rural areas $(0.3 \mathrm{pp})$. In non-rural areas, the relationship is negative for both men and women, with the magnitude of the effects being very similar. In general, these results are in line with what is found in Table 3, where although a negative relationship is observed between BMI and the probability of working, this effect is mainly concentrated in women, and those who are married and live in non-rural areas are the most affected.

\section{[Insert Table 6 over here.]}

A similar analysis for monthly wages is seen in Tables 7 and 8. In the case of those working in the formal sector (column 2), BMI is related to an increase in the wages of men (1.4\%) and a decrease in the case of women $(-1.2 \%)$. In both cases, the values are statistically significant. However, it is interesting to note that this relationship is concentrated in the BMI range of obesity (panel B). If these results are compared with those working in the informal sector (column 3), it can be seen that the positive relationship between obesity and wages is maintained in the case of men, the magnitudes being very similar. However, in the case of women, the signs found are maintained, but are not statistically significant. With respect to marital status and the area of

\footnotetext{
${ }^{9}$ It should be pointed out that the inclusion of BMI and its square value were not considered in the tables presented in this section, since values were not statistically significant.
} 
residence (rural or urban), the results found remain, that is, positive effects in the case of men and negative effects in the case of women.

[Insert Table 7 over here.]

[Insert Table 8 over here.]

Figures 3 to 8 in the Annex show the relationship between BMI and monthly wages at different points of the wage distribution. In general, the positive relationship between BMI and men's wages is maintained and tends to increase as moving forward in the distribution of income. This trend is maintained for each of the subgroups under study. In the case of women, the negative relationship is maintained, but varies across income quantiles. In this sense, among those who work in the formal sector and are married (Figures 3 and 5), it can be seen that this relationship has an inverted U-shape; that is, the negative effect is greater in the lower and upper quantiles. Further studies on this relationship may help to explain whether these findings are related to discrimination against women or self-selection in the income distribution tails. On the other hand, Figures 4, 6 and 8 show that the negative effect increases as moving in the distribution of income, as compared to those who work in the informal sector, are single or live in non-rural areas. Finally, in the case of women in rural areas the effect is constant across many income quantiles.

\section{Conclusions}

Peru is a middle-income country that has shown remarkable economic growth in recent decades. However, problems persist in the health system, as well as in the development of policies promoting the well-being of workers. In that sense, this paper seeks to approximate the relationship between obesity and both employment and wages in labor force in this country. Using data from the ENAHO-CENAN survey for the period 2007-2011, 48\% of working men are found to be in the normal BMI range, while $42 \%$ of women are in this same category. Regarding the overweight population, $40 \%$ of men and $38 \%$ of women are in this condition, while $12 \%$ of men and $20 \%$ of women are obese. 
Similarly, different behaviors were seen in the participation of men and women in the labor market as BMI increases. In men, the percentage increases until reaching the overweight range, and then slowly declines in the obesity range. In women, labor participation only increases in the normal range, then declines rapidly as BMI increases. Regarding wages, it can be seen that women's wages are higher than men's in the normal range of BMI, and then grow at a slower rate than in the case of men. Thus, between the normal range and the overweight range, women's income increases by $10 \%$, while in the case of men the increase is $40 \%$. Similarly, while women's wages decrease when they go from the overweight to the obese range, in men, wages do not decrease. In general, in the obesity range, men's wages are $22 \%$ higher than in the case of women.

Although the study only seeks to find associations and not causal effects, the application of OLS and quantile regressions show that an increase by one unit in BMI has a negative relationship with the probability of women working ( $-0.3 \mathrm{pp}$., on average), particularly among married women and those living in urban areas. In the case of men, the association is not statistically significant. On the other hand, an increase of one unit in BMI is associated with a reduction of $0.8 \%$ in women's monthly wages (US\$2.3, on average). This effect is observed at the top of the wage's distribution and among those in the BMI obesity range. In the case of men, the effect is positive and significant (additional US\$ 4.5, on average) in most of the subgroups analyzed. These results are close to those found in other countries, both in magnitudes and in a persistent negative effect on women. Further studies should not only focus on analyzing the possible causality of the findings found, but also seek to determine whether the wage penalty observed in women could be related to discriminatory effects on their appearance.

\section{References}

Agerström, J., \& Rooth, D. O. (2011). The role of automatic obesity stereotypes in real hiring discrimination. Journal of Applied Psychology, 96 (4), 790-805.

Ahn, R., Kim, T. H., \& Han, E. (2019). The moderation of obesity penalty on job market outcomes by employment efforts. International journal of environmental research and public health, 16 (16), 2974. 
Ahsan, M. N., \& Böckerman, P. (2019). Alternative measures of body composition and wage premium: New evidence from Indonesia, PloS one, 14 (8), 1-6.

Álvarez-Dongo, D., Sánchez-Abanto, J., Gómez-Guizado, J, \& Tarqui-Mamani, C. (2012) Sobrepeso y obesidad: prevalencia y determinantes sociales del exceso de peso en la población peruana (2009-2010). Revista Peruana de Medicina Experimental y Salud Pública, 29, 303-313.

Arceo-Gomez, E. O., \& Campos-Vazquez, R. M. (2014). Race and marriage in the labor market: A discrimination correspondence study in a developing country. American Economic Review, 104 (5), 376-380.

Asgeirsdottir, T. L. (2011). Do body weight and gender shape the work force? The case of Iceland. Economics \& Human Biology, 9 (2), 148-156.

Atella, V., Pace, N., \& Vuri, D. (2008). Are employers discriminating with respect to weight?: European evidence using quantile regression. Economics \& Human Biology, 6 (3), 305329.

Averett, S., \& Korenman, S. (1999). Black-white differences in social and economic consequences of obesity. International Journal of Obesity, 23 (2), 166-173.

Averett, S. L. (2019). Obesity and labor market outcomes. IZA World of Labor, 32.

Baum, C. L, \& Ford, W. F. (2004). The wage effects of obesity: a longitudinal study. Health economics, 13 (9), 885-899.

BCRP. (2018). Memoria 2018, Banco Central de Reserva del Perú.

Beauchamp, J. P., Cesarini, D., Johannesson, M., van der Loos, M. J., Koellinger, P. D., Groenen, P. J., .. \& Christakis, N. A. (2011). Molecular genetics and economics. Journal of Economic Perspectives, 25 (4), 57-82.

Benjamin, D. J., Cesarini, D., Chabris, C. F., Glaeser, E. L., Laibson, D. I., Age, Gene/Environment Susceptibility-Reykjavik Study:, ... \& Smith, A. V. (2012). The promises and pitfalls of genoeconomics, Annu. Rev. Econ., 4 (1), 627-662.

Biroli, P. (2015). Genetic and economic interaction in the formation of human capital: the case of obesity. Technical Report, Mimeo. University of Zurich.

Bozoyan, C., \& Wolbring, T. (2011). Fat, muscles, and wages. Economics \& Human Biology, 9 (4), 356-363. 
Bramming, M., Jørgensen, M. B., Christensen, A. I., Lau, C. J., Egan, K. K., \& Tolstrup, J. S. (2019). BMI and labor market participation: a cohort study of transitions between work, unemployment, and sickness absence. Obesity, 27 (10), 1703-1710.

Brunello, G., \& d'Hombres, B. (2005). Does obesity hurt your wages more in Dublin than in Madrid? Evidence from ECHP. Institute for the Study of Labor, IZA Working Paper 1704.

Brunello, G., \& d'Hombres, B. (2007). Does body weight affect wages?: Evidence from Europe. Economics \& Human Biology, 5 (1), 1-19.

Brunello, G., Anna Sanz-de-Galdeano, A., \& Terskaya, A. (2019). Not only in my genes: the effects of peers' genotype on obesity. Journal of Health Economics, 72, 102349.

Buchinsky, M. (2002). Quantile regression with sample selection: estimating women's return to education in the US, in Economic applications of quantile regression (pp. 87-113). Physica. Heidelberg.

Caliendo, M., \& Gehrsitz, M. (2016). Obesity and the labor market: A fresh look at the weight penalty. Economics \& Human Biology, 23, 209-225.

Caliendo, M., \& Lee, W. S. (2013). Fat chance! Obesity and the transition from unemployment to employment. Economics \& Human Biology, 11 (2), 121-133.

Campos-Vazquez, R. M., \& Gonzalez, E. (2020). Obesity and Hiring Discrimination. Economics \& Human Biology, 37, 100850.

Campos-Vazquez, R. M., \& Nuñez, R. (2019). Obesity and labor market outcomes in Mexico. Estudios Económicos, 34 (2), 159-196.

Carrillo, B., Queiroz, P. W. Charris, C. A., \& Coelho, A. B. (2017). New evidence of the effect of body weight on labor market outcomes in a developing country. Pesquisa $e$ planejamento econômico, 47 (2), 177-196.

Cawley, J. (2000). Body weight and women's labor market outcomes. National Bureau of Economic Research (NBER), NBER Working Papers 7841.

Cawley, J. (2004). The impact of obesity on wages. Journal of Human resources, 39 (2), 451474.

Cawley, J., Grabka, M. M., Lillard, D. R. (2005). A comparison of the relationship between obesity and earnings in the US and Germany. Schmollers Jahrbuch, 125 (1), 119-129.

Cawley, J., Han, E., \& Norton, E. C. (2011). The validity of genes related to neurotransmitters as instrumental variables. Health economics, 20 (8), 884-888. 
Cawley, J., Han, E., Kim, J. J., \& Norton, E. C. (2017). Testing for peer effects using genetic data. National Bureau of Economic Research (NBER), NBER Working Papers 23719.

Cawley, J., \& Meyerhoefer, C. (2012). The medical care costs of obesity: an instrumental variables approach. Journal of health economics, 31 (1), 219-230.

Clément, M., Levasseur, P., \& Seetahul, S. (2020). Is excess weight penalised or rewarded in middle-income countries' labour markets?. Kyklos, 73 (2), 161-195.

Colchero, M. A., \& Bishai, D. (2012). Weight and earnings among childbearing women in Metropolitan Cebu, Philippines (1983-2002). Economics \& Human Biology, 10 (3), 256263.

Conley, D. (2009). The promise and challenges of incorporating genetic data into longitudinal social science surveys and research. Biodemography and Social Biology, 55 (2), 238-251.

DeBeaumont, R. (2009). Occupational differences in the wage penalty for obese women. The Journal of Socio-Economics, 38 (2), 344-349.

DeBeaumont, R., \& Girtz, R. (2019). The mediation effect of self-esteem on weight and earnings. Atlantic Economic Journal, 47 (4), 415-427.

Dolton, P., \& Xiao, M. (2015). The intergenerational transmission of BMI in China. Economics \& Human Biology, 19, 90-113.

Ehmke, M. D., Warziniack, T., Schroeter, C., \& Morgan, K. (2008). Applying experimental economics to obesity in the family household. Journal of Agricultural and Applied Economics, 40 (2), 539-549.

Galarza, F. B., \& Yamada, G. (2014). Labor market discrimination in Lima, Peru: evidence from a field experiment. World Development, 58, 83-94.

Garcia, J., \& Quintana-Domeque, C. (2006). Obesity, employment and wages in Europe. Advances in health economics and health services research, 17, 187-217.

Garcia, J., \& Quintana-Domeque, C. (2009). Income and body mass index in Europe. Economics \& Human Biology, 7 (1), 73-83.

Gortmaker, S. L., Must, A., Perrin, J. M., Sobol, A. M., \& Dietz, W. H. (1993). Social and economic consequences of overweight in adolescence and young adulthood. New England journal of medicine, 329 (14), 1008-1012.

Gregory, C. A., \& Ruhm, C. J. (2011). Where does the wage penalty bite?. In N. Mocan \& M. Grossman (Eds.). Economic Aspects of obesity (315-347). University of Chicago Press. 
Greve, J. (2008). Obesity and labor market outcomes in Denmark. Economics \& Human Biology, $6(3), 350-362$.

Han, E., Norton, E. C., \& Powell, L. M. (2011). Direct and indirect effects of body weight on adult wages. Economics \& Human Biology, 9 (4), 381-392.

Han, E., Norton, E. C., \& Stearns, S. C. (2009). Weight and wages: fat versus lean paychecks. Health economics, 18 (5), 535-548.

Heckman, J. (1979). Sample Selection Bias as a Specification Error. Econometrica, 47 (1), 153161.

Herrera, B. M., Keildson, S., \& Lindgren, C. M. (2011). Genetics and epigenetics of obesity. Maturitas 69 (1), 41-49.

Hildebrand, V., \& Van Kerm. P. (2010). Body size and wages in Europe: a semi-parametric analysis, McMaster University.

Howe, L. D., Kanayalal, R., Harrison, S., Beaumont, R. N., Davies, A. R., Frayling, T. M., ... \& Wood, A. R. (2019). Effects of body mass index on relationship status, social contact, and socioeconomic position: Mendelian randomization study in UK Biobank. BioRxiv, 524488 .

INEI (2011). Ficha técnica: monitoreo de indicadores nutricionales en la encuesta nacional de salud de hogares. Instituto Nacional de Estadística e Informática.

INEI (2019). Comportamiento de los indicadores de mercado laboral a nivel nacional. Instituto Nacional de Estadística e Informática.

Jay, P., \& Xuezheng. Q. (2013). The impact of body size on urban employment: evidence from China. China Economic Review, 27, 249-263.

Johansson, E., Bockerman, P., Kiiskinen, U., \& Heliövaara, M. (2009). Obesity and labour market success in Finland: the difference between having a high BMI and being fat. Economics \& Human Biology, 7 (1), 36-45.

Johar, M., \& Katayama, H. (2012). Quantile regression analysis of body mass and wages. Health Economics, 21 (5), 597-611.

Koenker, R., \& Bassett Jr, G. (1978). Regression quantiles. Econometrica: journal of the Econometric Society, 33-50.

Kortt, M., \& Leigh, A. (2010). Does size matter in Australia?. Economic Record, 86 (272), 7183. 
Lakdawalla, D., \& Philipson, T. (2002). The growth of obesity and technological change: a theoretical and empirical examination. National Bureau of Economic Research (NBER), NBER Working Papers 8946.

Lindeboom, M., Lundborg, P., \& van der Klaauw, B. (2009). Obesity and labor market outcomes: evidence from the British NCDS. Institute for the Study of Labor (IZA), IZA Working Paper 4099.

Locke, A. E., Kahali, B., Berndt, S. I., Justice, A. E., Pers, T. H., Day, F. R., ... \& CroteauChonka, D. C. (2015). Genetic studies of body mass index yield new insights for obesity biology. Nature, 518 (7538), 197-206.

Loh, E. S. (1993). The economic effects of physical appearance. Social Science Quarterly, 420438.

Lundborg, P., Nystedt, P., \& Rooth, D. O. (2010). No country for fat men? Obesity, earnings, skills, and health among 450,000 Swedish men. Institute for Study of Labor (IZA), IZA Working Paper 4775.

Lundborg, P., Nystedt, P., \& Rooth, D. O. (2014). Body size, skills, and income: evidence from 150,000 teenage siblings. Demography. 51 (5), 1573-1596.

Mitra, A. (2001). Effects of physical attributes on the wages of males and females. Applied Economics Letters, 8 (11), 731-735.

Mocan, N., \& Tekin, E. (2011). Obesity, self-esteem and wages. In N. Mocan \& M. Grossman (Eds.). Economic aspects of obesity (349-380). University of Chicago Press.

Morris, S. (2006). Body mass index and occupational attainment. Journal of health economics, 25 (2), 347-364.

Morris, S. (2007). The impact of obesity on employment. Labour Economics, 14 (3), 413-433.

Norton, E. C., \& Han, E. (2008). Genetic information, obesity, and labor market outcomes. Health economics, 17 (9), 1089-1104.

OECD (2019). Health at a Glance 2019: OECD Indicators. OECD.

Pagan, J. A., \& Davila, A. (1997). Obesity, occupational attainment, and earnings. Social Science Quarterly, 78 (3) 756-770.

Philipson, T. J., \& Posner, R. A. (1999). The long-run growth in obesity as a function of technological change. National Bureau of Economic Research (NBER), NBER Working Paper 7423. 
Pinkston, J. C. (2017). The dynamic effects of obesity on the wages of young workers. Economics \& Human Biology, 27, 154-166.

Ramsey, J. B. (1969). Tests for specification error in classical linear least-squares regression analysis. Journal of the Royal Statistical Society: Series B (Methodological), 31 (2), 350371.

Register, C. A., \& Williams, D. R. (1990). Wage effects of obesity among young workers. Social Science Quarterly, 71 (1), 130.

Revilla, L., Alvarado, C., Álvarez, D., Tarqui, C., Gómez, G., Jacoby, E., \& Sanchez-Griñan, M. (2012). Un gordo problema: sobrepeso y obesidad en el Perú. Lima: Ministerio de Salud, $1,21$.

Sabia, J. J., \& Rees, D. I. (2012). Body weight and wages: evidence from Add Health. Economics \& Human Biology, 10 (1), 14-19.

Savona-Ventura, C., \& Savona-Ventura, S. (2015). The inheritance of obesity. Best Practice \& Research Clinical Obstetrics \& Gynaecology, 29 (3), 300-308.

Schwalb, M. M., Sanborn, C., Galarza, F., Garcia, E., Kogan, L., Mayorga Gutiérrez, D., ... \& Runciman Saettone, G. (2014). Comida chatarra, estado y mercado. Universidad del Pacífico.

Shimokawa, S. (2008). The labour market impact of body weight in China: a semiparametric analysis. Applied Economics, 40 (8), 949-968.

Thompson, D., Edelsberg, J., Colditz, G. A., Bird, A. P., \& Oster, G. (1999). Lifetime health and economic consequences of obesity. Archives of internal medicine, 159 (18), 2177-2183.

von Hinke Kessler Scholder, S., Smith, G. D., Lawlor, D. A., Propper, C., \& Windmeijer, F, (2010). Genetic markers as instrumental variables: An application to child fat mass and academic achievement. Center for Microdata Methods and Practice (CEMMAP), CEMMAP Working Paper 03/10.

Wada, R., \& Tekin, E. (2010). Body composition and wages. Economics \& Human Biology, 8 (2), 242-254.

WHO (2018). World health statistics 2018: Monitoring health for the SDGs, sustainable development goals, World Health Organization. 


\section{Tables and figures}

\section{Figure 1: BMI by sex}

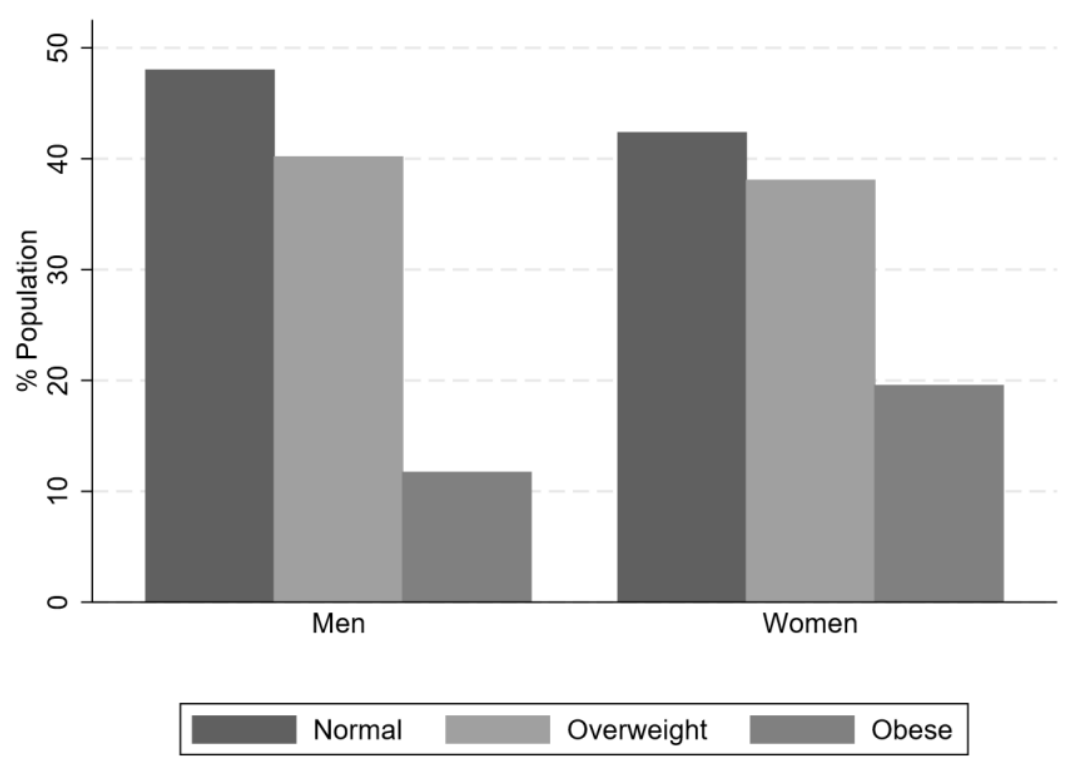

Note: Author's calculations, using data from the ENAHO-CENAN 2007-2011. Men and women aged 15-65 years. Severely obese is included with obese. $\mathrm{N}=45,172$. 


\section{Figure 2: Labor market outcomes and BMI}
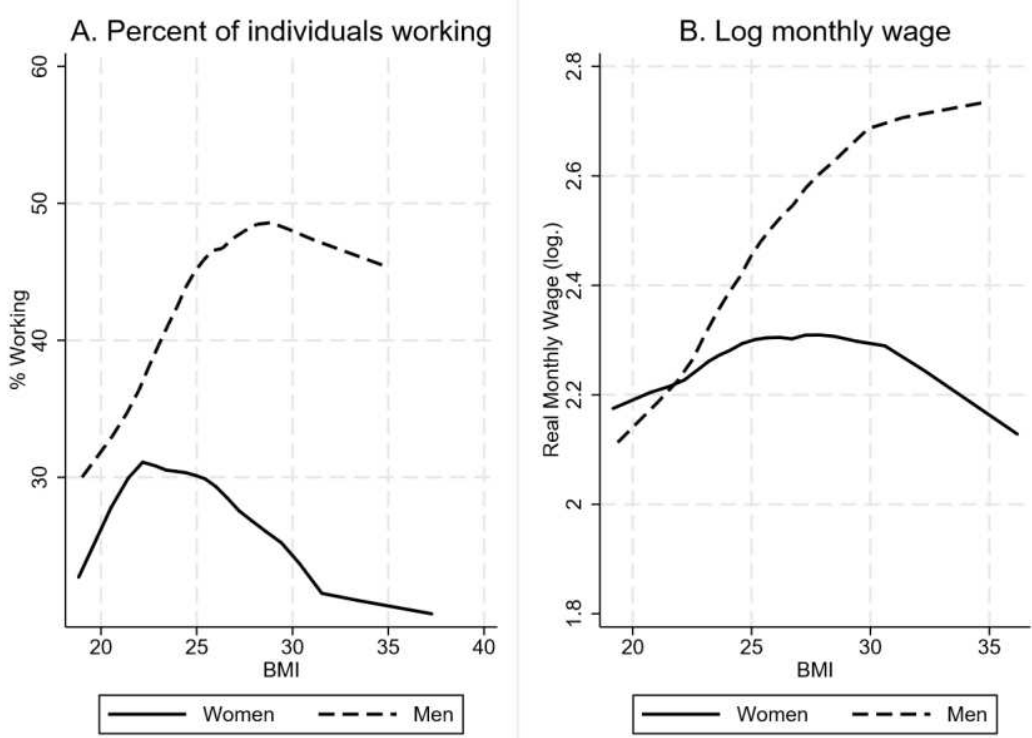

Note: Author'scalculations, using data from the ENAHO-CENAN 2007-2011. Data restricted to individuals with valid observations aged 15-65 years and BMI from 15 to 45 . In panel $\mathrm{A}, \mathrm{N}=45,172$ (49.1\% women); in panel $\mathrm{B}$, $\mathrm{N}=13,414$ (35.9\% women). We define 20 quantiles of BMI by sex to generate a Lowess graph (using expansion weights in both panels). 
Table 1: Descriptive statistics

\begin{tabular}{|c|c|c|c|c|}
\hline & \multicolumn{2}{|c|}{$\begin{array}{l}\text { All } \\
(1)\end{array}$} & \multicolumn{2}{|c|}{$\begin{array}{l}\text { Restricted } \\
\text { (2) }\end{array}$} \\
\hline & Men & Women & Men & Women \\
\hline No. of observations & 22,983 & 22,189 & 8,596 & 4,818 \\
\hline BMI & 25.5 & 26.3 & 25.9 & 25.9 \\
\hline Standard deviation & 3.8 & 4.5 & 3.7 & 4.1 \\
\hline $\mathrm{BMI} \leq 25(\%)$ & 48.0 & 42.3 & 42.0 & 45.2 \\
\hline Overweight $(\%)(25<\mathrm{BMI} \leq 30)$ & 40.2 & 38.1 & 45.6 & 40.1 \\
\hline Obese and severely obese $(\%)(\mathrm{BMI}>30)$ & 11.8 & 19.6 & 12.4 & 14.8 \\
\hline Waist circumference $(\mathrm{cm})$ & 88.5 & 86.8 & 89.3 & 85.8 \\
\hline Standard deviation & 10.6 & 11.5 & 10.1 & 11.0 \\
\hline Age (years) & 37.9 & 38.1 & 36.4 & 36.1 \\
\hline Married (\%) & 65.3 & 60.1 & 64.8 & 46.7 \\
\hline Rural (\%) & 26.7 & 26.7 & 12.6 & 6.2 \\
\hline Speaks an indigenous language $(\%)$ & 19.1 & 22.0 & 13.1 & 8.8 \\
\hline Health problems $(\%)$ & 53.1 & 53.0 & 55.7 & 57.7 \\
\hline Years of schooling & 13.0 & 11.7 & 14.3 & 15.4 \\
\hline At least a university degree $(\%)$ & 16.3 & 13.3 & 22.4 & 30.4 \\
\hline Children 6-19 years old living in household (\%) & 52.3 & 54.3 & 51.2 & 46.0 \\
\hline Participation in the labor force $(\%)$ & 43.4 & 27.6 & 100.0 & 100.0 \\
\hline Working hours per week & & & 47.6 & 42.6 \\
\hline Monthly wage (soles) & & & $1,167.8$ & 957.3 \\
\hline Full time employment (\%) & & & 89.2 & 82.6 \\
\hline Informal employment (\%) & & & 49.5 & 45.4 \\
\hline
\end{tabular}

Notes: Author's calculations, using data from the ENAHO-CENAN 2007-2011. Column 1 presents data for all individuals with valid observations for the variables employed; column 2 shows data only for workers with valid observations. Marriage includes cohabitation. Health problems refer to a family history of diseases. Wages given in constant soles from September 2019. Full-time refers to at least 30 hours of work during the referenced week. Informal work is defined as work without access to healthcare services. Waist circumference is observed for $77.7 \%$ of the sample in column 1 and $78 \%$ in column 2. 


\section{Table 2: Sample restriction}

\begin{tabular}{lr}
\hline Initial sample & 146,037 \\
Working people from 15-65 & 65,614 \\
Height and weight both valid & 49,091 \\
Not pregnant & 48,474 \\
$15<=$ BMI <= 45 & 48,400 \\
Monthly wages > = 250 & 45,172 \\
\hline
\end{tabular}

Notes: Author's calculations, using data from the ENAHO-CENAN 2007-2011. Only individuals with height between one and 2.2 meters and weight between 20 and $220 \mathrm{~kg}$ were included. Wages given in constant soles from September 2019. 
Table 3: Results on employment

\begin{tabular}{|c|c|c|}
\hline & Men & Women \\
\hline \multicolumn{3}{|c|}{ Panel A } \\
\hline \multirow[t]{2}{*}{ BMI } & -0.002 & $-0.003 * * *$ \\
\hline & $(0.001)$ & $(0.001)$ \\
\hline $\mathrm{N}$ & 22,983 & 22,189 \\
\hline \multirow[t]{2}{*}{ R-2 adj. } & 0.452 & 0.533 \\
\hline & Panel B & \\
\hline \multirow[t]{2}{*}{ BMI } & $0.029 * * *$ & 0.003 \\
\hline & $(0.010)$ & $(0.007)$ \\
\hline \multirow[t]{2}{*}{ BMI squared } & $-0.001 * * *$ & -0.000 \\
\hline & $(0.000)$ & $(0.000)$ \\
\hline $\mathrm{N}$ & 22,983 & 22,189 \\
\hline \multirow[t]{2}{*}{ R-2 adj. } & 0.453 & 0.533 \\
\hline & Panel C & \\
\hline \multirow[t]{2}{*}{ Overweight } & -0.003 & $-0.014^{*}$ \\
\hline & $(0.010)$ & $(0.008)$ \\
\hline \multirow[t]{2}{*}{ Obese } & $-0.049 * * *$ & $-0.043 * * *$ \\
\hline & $(0.013)$ & $(0.010)$ \\
\hline $\mathrm{N}$ & 22,983 & 22,189 \\
\hline R-2 adj. & 0.453 & 0.533 \\
\hline \multicolumn{3}{|c|}{$\begin{array}{l}\text { Notes: Author's calculations, using data } \\
\text { from the ENAHO-CENAN 2007-2011. } \\
\text { Robust standard errors in parentheses. } \\
* * * \text { p }<0.01, * * \mathrm{p}<0.05, * \mathrm{p}<0.1 \text {. Both } \\
\text { regressions include the following variables: } \\
\text { age, age squared, dummies of rural, } \\
\text { geographic area, year of the survey, speaks } \\
\text { an indigenous language, literacy, married, } \\
\text { formal labor, studies in private or public } \\
\text { school, variables of health problems, } \\
\text { experience and experience squared. }\end{array}$} \\
\hline
\end{tabular}


Table 4: Results on monthly wages (in logs.)

\begin{tabular}{|c|c|c|c|c|c|c|}
\hline & \multicolumn{2}{|c|}{ (1) } & \multicolumn{2}{|c|}{ (2) } & \multicolumn{2}{|c|}{ (3) } \\
\hline & Men & Women & Men & Women & Men & Women \\
\hline \multicolumn{7}{|c|}{ Panel A } \\
\hline BMI & $\begin{array}{c}0.013 * * * \\
(0.003)\end{array}$ & $\begin{array}{c}-0.008 * * * \\
(0.003)\end{array}$ & $\begin{array}{c}0.013 * * * \\
(0.003)\end{array}$ & $\begin{array}{c}-0.008 * * * \\
(0.003)\end{array}$ & $\begin{array}{c}0.013 * * * \\
(0.005)\end{array}$ & $\begin{array}{c}-0.008 * * \\
(0.004)\end{array}$ \\
\hline $\mathrm{N}$ & 8,596 & 4,818 & 8,596 & 4,818 & 3,187 & 1,691 \\
\hline R-2 adj. & 0.425 & 0.481 & & & & \\
\hline Wald test & & & 88.40 & 4.343 & 23.89 & 24.18 \\
\hline P-val & & & 0.000 & 0.037 & 0.000 & 0.000 \\
\hline \multicolumn{7}{|c|}{ Panel B } \\
\hline BMI & $\begin{array}{c}0.027 \\
(0.023)\end{array}$ & $\begin{array}{l}-0.016 \\
(0.021)\end{array}$ & $\begin{array}{c}0.016 \\
(0.022)\end{array}$ & $\begin{array}{l}-0.012 \\
(0.022)\end{array}$ & $\begin{array}{c}0.008 \\
(0.053)\end{array}$ & $\begin{array}{l}-0.008 \\
(0.033)\end{array}$ \\
\hline BMI squared & $\begin{array}{l}-0.000 \\
(0.000)\end{array}$ & $\begin{array}{c}0.000 \\
(0.000)\end{array}$ & $\begin{array}{l}-0.000 \\
(0.000)\end{array}$ & $\begin{array}{c}0.000 \\
(0.000)\end{array}$ & $\begin{array}{c}0.000 \\
(0.001)\end{array}$ & $\begin{array}{l}-0.000 \\
(0.001)\end{array}$ \\
\hline $\mathrm{N}$ & 8,596 & 4,818 & 8,596 & 4,818 & 3,187 & 1,691 \\
\hline R-2 adj. & 0.425 & 0.481 & & & & \\
\hline Wald test & & & 89.98 & 4.442 & 26.03 & 24.19 \\
\hline P-val & & & 0.000 & 0.035 & 0.000 & 0.000 \\
\hline & & & Panel C & & & \\
\hline Overweight & $\begin{array}{l}0.039 * \\
(0.020)\end{array}$ & $\begin{array}{l}-0.049 * \\
(0.026)\end{array}$ & $\begin{array}{c}0.040 * * \\
(0.020)\end{array}$ & $\begin{array}{c}-0.050 * \\
(0.026)\end{array}$ & $\begin{array}{c}0.020 \\
(0.032)\end{array}$ & $\begin{array}{l}-0.028 \\
(0.047)\end{array}$ \\
\hline Obese & $\begin{array}{c}0.119 * * * \\
(0.031)\end{array}$ & $\begin{array}{c}-0.094 * * * \\
(0.028)\end{array}$ & $\begin{array}{c}0.133 * * * \\
(0.031)\end{array}$ & $\begin{array}{c}-0.102 * * * \\
(0.028)\end{array}$ & $\begin{array}{c}0.120 * * \\
(0.049)\end{array}$ & $\begin{array}{l}-0.046 \\
(0.046)\end{array}$ \\
\hline $\mathrm{N}$ & 8,596 & 4,818 & 8,596 & 4,818 & 3,187 & 1,691 \\
\hline $\mathrm{R}-2$ adj. & 0.423 & 0.481 & & & & \\
\hline Wald test & & & 87.87 & 4.840 & 23.43 & 22.16 \\
\hline P-val & & & 0.000 & 0.028 & 0.000 & 0.000 \\
\hline
\end{tabular}

Notes: Author's calculations, using data from the ENAHO-CENAN 2007-2011. Robust standard errors in parentheses. Wages given in Peruvian soles from September 2019. ***p $<0.01$, ${ }^{* *} \mathrm{p}<0.05,{ }^{*} \mathrm{p}<0.1$. Both regressions include the following variables: age, age squared, dummies of rural, geographic area, year of the survey, speaks an indigenous language, literacy, married, formal labor, studies in private or public school, variables of health problems, experience and experience squared. Column 1 does not correct for selection bias; column 2 corrects selection bias but it does not include an extra variable in the selection equation; column 3 includes the average age of children from 6 to 19 living in the household as an instrument in the selection equation. 
Table 5: Results on monthly wages by quantiles (in logs.)

\begin{tabular}{|c|c|c|c|c|c|c|c|c|c|c|}
\hline \multirow[b]{2}{*}{ quantile } & \multicolumn{5}{|c|}{ Men } & \multicolumn{5}{|c|}{ Women } \\
\hline & 0.150 & 0.250 & 0.500 & 0.750 & 0.850 & 0.150 & 0.250 & 0.500 & 0.750 & 0.850 \\
\hline \multicolumn{11}{|c|}{ Panel A } \\
\hline BMI & $\begin{array}{c}0.008 * * * \\
(0.002)\end{array}$ & $\begin{array}{c}0.008 * * * \\
(0.002)\end{array}$ & $\begin{array}{c}0.015 * * * \\
(0.003)\end{array}$ & $\begin{array}{c}0.016 * * * \\
(0.003)\end{array}$ & $\begin{array}{c}0.017 * * * \\
(0.003)\end{array}$ & $\begin{array}{l}-0.003 \\
(0.003)\end{array}$ & $\begin{array}{l}-0.003 \\
(0.002)\end{array}$ & $\begin{array}{l}-0.001 \\
(0.003)\end{array}$ & $\begin{array}{c}-0.006^{* *} \\
(0.002)\end{array}$ & $\begin{array}{c}-0.012 * * * \\
(0.003)\end{array}$ \\
\hline $\mathrm{N}$ & 8,596 & 8,596 & 8,596 & 8,596 & 8,596 & 4,818 & 4,818 & 4,818 & 4,818 & 4,818 \\
\hline \multicolumn{11}{|c|}{ Panel B } \\
\hline BMI & $\begin{array}{c}0.034 * * * \\
(0.012)\end{array}$ & $\begin{array}{c}0.032 \\
(0.023)\end{array}$ & $\begin{array}{c}0.042 * * * \\
(0.012)\end{array}$ & $\begin{array}{c}0.027 \\
(0.019)\end{array}$ & $\begin{array}{c}0.017 \\
(0.039)\end{array}$ & $\begin{array}{l}-0.024 \\
(0.018)\end{array}$ & $\begin{array}{c}0.003 \\
(0.012)\end{array}$ & $\begin{array}{c}0.015 \\
(0.018)\end{array}$ & $\begin{array}{c}0.007 \\
(0.025)\end{array}$ & $\begin{array}{l}-0.022 \\
(0.028)\end{array}$ \\
\hline BMI squared & $\begin{array}{c}-0.000 * * \\
(0.000)\end{array}$ & $\begin{array}{l}-0.000 \\
(0.000)\end{array}$ & $\begin{array}{c}-0.000 * * \\
(0.000)\end{array}$ & $\begin{array}{l}-0.000 \\
(0.000)\end{array}$ & $\begin{array}{c}0.000 \\
(0.001)\end{array}$ & $\begin{array}{c}0.000 \\
(0.000)\end{array}$ & $\begin{array}{l}-0.000 \\
(0.000)\end{array}$ & $\begin{array}{l}-0.000 \\
(0.000)\end{array}$ & $\begin{array}{l}-0.000 \\
(0.000)\end{array}$ & $\begin{array}{c}0.000 \\
(0.000)\end{array}$ \\
\hline $\mathrm{N}$ & 8,596 & 8,596 & 8,596 & 8,596 & 8,596 & 4,818 & 4,818 & 4,818 & 4,818 & 4,818 \\
\hline \multicolumn{11}{|c|}{ Panel C } \\
\hline Overweight & $\begin{array}{c}0.013 \\
(0.018)\end{array}$ & $\begin{array}{c}0.014 \\
(0.015)\end{array}$ & $\begin{array}{c}0.044 * * \\
(0.020)\end{array}$ & $\begin{array}{c}0.064 * * * \\
(0.024)\end{array}$ & $\begin{array}{c}0.089 * * * \\
(0.032)\end{array}$ & $\begin{array}{c}-0.049 * * \\
(0.022)\end{array}$ & $\begin{array}{l}-0.038^{*} \\
(0.023)\end{array}$ & $\begin{array}{c}0.019 \\
(0.024)\end{array}$ & $\begin{array}{l}-0.012 \\
(0.023)\end{array}$ & $\begin{array}{l}-0.032 \\
(0.034)\end{array}$ \\
\hline Obese & $\begin{array}{c}0.060 * * * \\
(0.020)\end{array}$ & $\begin{array}{c}0.054 * * \\
(0.024)\end{array}$ & $\begin{array}{c}0.135 * * * \\
(0.031)\end{array}$ & $\begin{array}{c}0.166^{* * *} \\
(0.038)\end{array}$ & $\begin{array}{c}0.205^{* * *} \\
(0.046)\end{array}$ & $\begin{array}{c}0.001 \\
(0.029)\end{array}$ & $\begin{array}{l}-0.020 \\
(0.030)\end{array}$ & $\begin{array}{l}-0.012 \\
(0.030)\end{array}$ & $\begin{array}{c}-0.091 * * * \\
(0.026)\end{array}$ & $\begin{array}{c}-0.143 * * * \\
(0.039)\end{array}$ \\
\hline $\mathrm{N}$ & 8,596 & 8,596 & 8,596 & 8,596 & 8,596 & 4,818 & 4,818 & 4,818 & 4,818 & 4,818 \\
\hline
\end{tabular}

Notes: Author's calculations, using data from the ENAHO-CENAN 2007-2011. Robust standard errors in parentheses. Wages given in Peruvian soles from September 2019. ${ }^{* * *} \mathrm{p}<0.01,{ }^{*} \mathrm{p}<0.05,{ }^{*} \mathrm{p}<0.1$. Both regressions include the following variables: age, age squared, dummies of rural, geographic area, year of the survey, speaks an indigenous language, literacy, married, formal labor, studies in private or public school, variables of health problems, experience and experience squared. 
Table 6: Results on employment by groups

\begin{tabular}{lcccccccc}
\hline & \multicolumn{2}{c}{ Married } & \multicolumn{2}{c}{ Single } & \multicolumn{2}{c}{ Rural } & \multicolumn{2}{c}{ Non-rural } \\
& Men & Women & Men & Women & Men & Women & Men & Women \\
\hline \multirow{2}{*}{ BMI } & & & \multicolumn{3}{c}{ Panel A } & & & \\
& $-0.003^{* *}$ & $-0.003^{* * *}$ & 0.000 & -0.002 & $0.003^{* *}$ & 0.001 & $-0.003^{* *}$ & $-0.004^{* * *}$ \\
N & $(0.001)$ & $(0.001)$ & $(0.002)$ & $(0.002)$ & $(0.002)$ & $(0.001)$ & $(0.001)$ & $(0.001)$ \\
R-2 adj. & 15,461 & 13,944 & 7,522 & 8,245 & 9,089 & 8,764 & 13,894 & 13,425 \\
& 0.531 & 0.621 & 0.310 & 0.427 & 0.382 & 0.302 & 0.423 & 0.515 \\
Overweight & & & & Panel B & & & & \\
& -0.002 & $-0.020^{* *}$ & -0.009 & -0.001 & 0.017 & 0.005 & -0.017 & $-0.023^{*}$ \\
Obese & $-0.011)$ & $(0.009)$ & $(0.018)$ & $(0.015)$ & $(0.012)$ & $(0.007)$ & $(0.012)$ & $(0.012)$ \\
& $-0.051^{* * *}$ & $-0.035^{* * *}$ & -0.042 & $-0.053 * *$ & -0.024 & 0.012 & $-0.056^{* * *}$ & $-0.056^{* * *}$ \\
N & $(0.015)$ & $(0.011)$ & $(0.029)$ & $(0.021)$ & $(0.020)$ & $(0.012)$ & $(0.015)$ & $(0.013)$ \\
R-2 adj. & 15,461 & 13,944 & 7,522 & 8,245 & 9,089 & 8,764 & 13,894 & 13,425 \\
\hline
\end{tabular}

Notes: Author's calculations, using data from the ENAHO-CENAN 2007-2011. Robust standard errors in parentheses. $* * * \mathrm{p}<0.01, * * \mathrm{p}<0.05, * \mathrm{p}<0.1$. Both regressions include the following variables: age, age squared, dummies of rural, geographic area, year of the survey, speaks an indigenous language, literacy, married, formal labor, studies in private or public school, variables of health problems, experience and experience squared. 
Table 7: Results on monthly wages (in logs.)

\begin{tabular}{|c|c|c|c|c|c|c|c|c|}
\hline & \multicolumn{2}{|c|}{ Formal } & \multicolumn{2}{|c|}{ Informal } & \multicolumn{2}{|c|}{ Married } & \multicolumn{2}{|c|}{ Single } \\
\hline & Men & Women & Men & Women & Men & Women & Men & Women \\
\hline \multicolumn{9}{|c|}{ Panel A } \\
\hline BMI & $\begin{array}{c}0.014 * * * \\
(0.004)\end{array}$ & $\begin{array}{c}-0.012 * * * \\
(0.004)\end{array}$ & $\begin{array}{c}0.011 * * * \\
(0.003)\end{array}$ & $\begin{array}{l}-0.005 \\
(0.004)\end{array}$ & $\begin{array}{c}0.012 * * * * \\
(0.004)\end{array}$ & $\begin{array}{c}-0.008 * * \\
(0.004)\end{array}$ & $\begin{array}{c}0.014 * * * * \\
(0.004)\end{array}$ & $\begin{array}{c}-0.007 * \\
(0.004)\end{array}$ \\
\hline $\mathrm{N}$ & 4,145 & 2,690 & 4,451 & 2,128 & 5,685 & 2,337 & 2,911 & 2,481 \\
\hline R-2 adj. & 0.222 & 0.297 & 0.188 & 0.133 & 0.393 & 0.506 & 0.430 & 0.446 \\
\hline \multicolumn{9}{|c|}{ Panel B } \\
\hline Overweight & $\begin{array}{c}0.046 \\
(0.033)\end{array}$ & $\begin{array}{l}-0.062 \\
(0.038)\end{array}$ & $\begin{array}{c}0.030 \\
(0.023)\end{array}$ & $\begin{array}{l}-0.043 \\
(0.035)\end{array}$ & $\begin{array}{c}0.031 \\
(0.026)\end{array}$ & $\begin{array}{l}-0.022 \\
(0.040)\end{array}$ & $\begin{array}{l}0.055^{*} \\
(0.032)\end{array}$ & $\begin{array}{l}-0.057 \\
(0.035)\end{array}$ \\
\hline Obese & $\begin{array}{c}0.120 * * * \\
(0.046)\end{array}$ & $\begin{array}{c}-0.145^{* * *} \\
(0.039)\end{array}$ & $\begin{array}{c}0.100 * * * \\
(0.039)\end{array}$ & $\begin{array}{l}-0.043 \\
(0.040)\end{array}$ & $\begin{array}{c}0.115^{* * *} \\
(0.039)\end{array}$ & $\begin{array}{l}-0.076^{*} \\
(0.039)\end{array}$ & $\begin{array}{c}0.114 * * \\
(0.045)\end{array}$ & $\begin{array}{c}-0.100 * * \\
(0.040)\end{array}$ \\
\hline $\mathrm{N}$ & 4,145 & 2,690 & 4,451 & 2,128 & 5,685 & 2,337 & 2,911 & 2,481 \\
\hline R-2 adj. & 0.220 & 0.298 & 0.185 & 0.132 & 0.392 & 0.505 & 0.426 & 0.447 \\
\hline
\end{tabular}

Notes: Author's calculations, using data from the ENAHO-CENAN 2007-2011. Robust standard errors in parentheses. Wages given in Peruvian soles from September 2019. ***p $<0.01, * * \mathrm{p}<0.05$, ${ }^{*} \mathrm{p}<0.1$. Both regressions include the following variables: age, age squared, dummies of rural, geographic area, year of the survey, speaks an indigenous language, literacy, married, formal labor, studies in private or public school, variables of health problems, experience and experience squared. 
Table 8: Results on monthly wages (in logs.)

\begin{tabular}{|c|c|c|c|c|}
\hline & \multicolumn{2}{|c|}{ Rural } & \multicolumn{2}{|c|}{ Non-rural } \\
\hline & Men & Women & Men & Women \\
\hline \multicolumn{5}{|c|}{ Panel A } \\
\hline \multirow[t]{2}{*}{ BMI } & $0.015 * * *$ & 0.003 & $0.013 * * *$ & $-0.008 * * *$ \\
\hline & $(0.005)$ & $(0.005)$ & $(0.003)$ & $(0.003)$ \\
\hline $\mathrm{N}$ & 1,799 & 583 & 6,797 & 4,235 \\
\hline \multirow[t]{2}{*}{ R-2 adj. } & 0.418 & 0.526 & 0.396 & 0.472 \\
\hline & & Panel B & & \\
\hline \multirow[t]{2}{*}{ Overweight } & 0.038 & 0.010 & 0.037 & $-0.048 *$ \\
\hline & $(0.030)$ & $(0.046)$ & $(0.023)$ & $(0.028)$ \\
\hline \multirow[t]{2}{*}{ Obese } & $0.177 * * *$ & 0.036 & $0.110 * * *$ & $-0.101 * * *$ \\
\hline & $(0.054)$ & $(0.062)$ & $(0.033)$ & $(0.030)$ \\
\hline $\mathrm{N}$ & 1,799 & 583 & 6,797 & 4,235 \\
\hline R-2 adj. & 0.417 & 0.525 & 0.394 & 0.472 \\
\hline \multicolumn{5}{|c|}{$\begin{array}{l}\text { Notes: Author's calculations, using data from the ENAHO-CENAN } \\
\text { 2007-2011. Robust standard errors in parentheses. Wages given in } \\
\text { Peruvian soles from September 2019. ***p }<0.01 \text {, **p }<0.05 \text {, } \\
\text { *p }<0.1 \text {. Both regressions include the following variables: age, age } \\
\text { squared, dummies of rural, geographic area, year of the survey, } \\
\text { speaks an indigenous language, literacy, married, formal labor, } \\
\text { studies in private or public school, variables of health problems, } \\
\text { experience and experience squared. }\end{array}$} \\
\hline
\end{tabular}




\section{Appendix}

\section{Figure 3: Monthly wages in the formal sector}
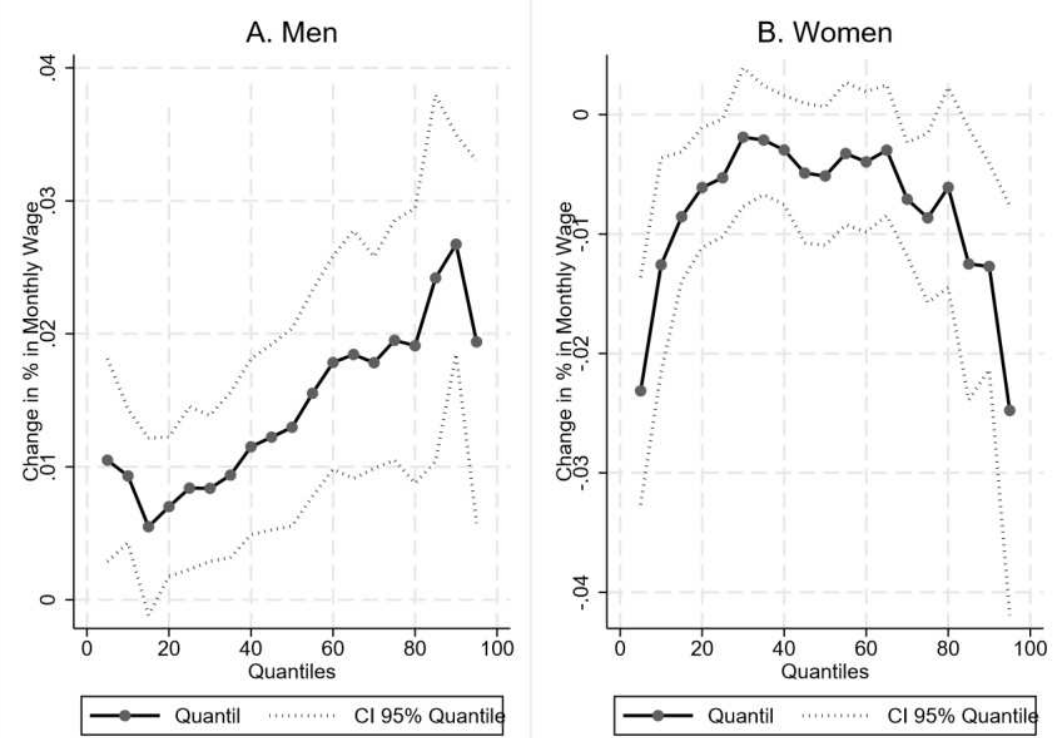

Notes: Author's calculations, using data from the ENAHO-CENAN 20072011. Robust standard errors in parentheses. Wages given in Peruvian soles from September 2019. ***p<0.01, **p<0.05, *p<0.1. Both regressions include the following variables: age, age squared, dummies of rural, geographic area, year of the survey, speaks an indigenous language, literacy, married, formal labor, studies in private or public school, variables of health problems, experience and experience squared. 


\section{Figure 4: Monthly wages in the informal sector}
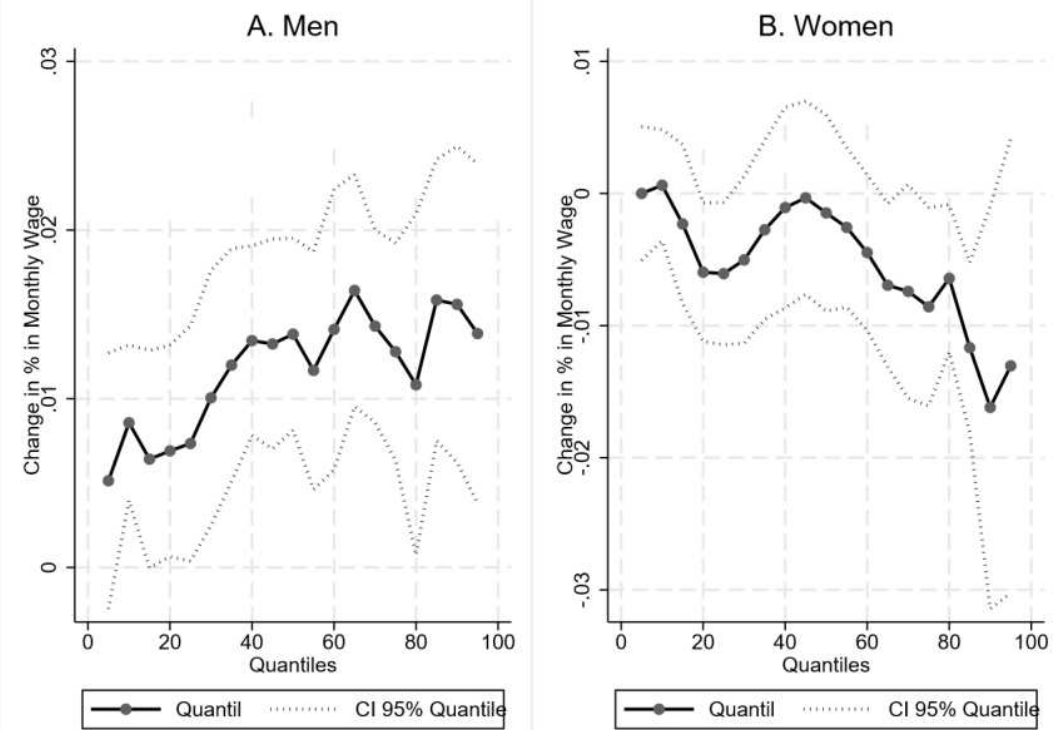

Notes: Author's calculations, using data from the ENAHO-CENAN 20072011. Robust standard errors in parentheses. Wages given in Peruvian soles from September 2019. ***p<0.01, **p<0.05, *p<0.1. Both regressions include the following variables: age, age squared, dummies of rural, geographic area, year of the survey, speaks an indigenous language, literacy, married, formal labor, studies in private or public school, variables of health problems, experience and experience squared. 


\section{Figure 5: Monthly wages in married people}
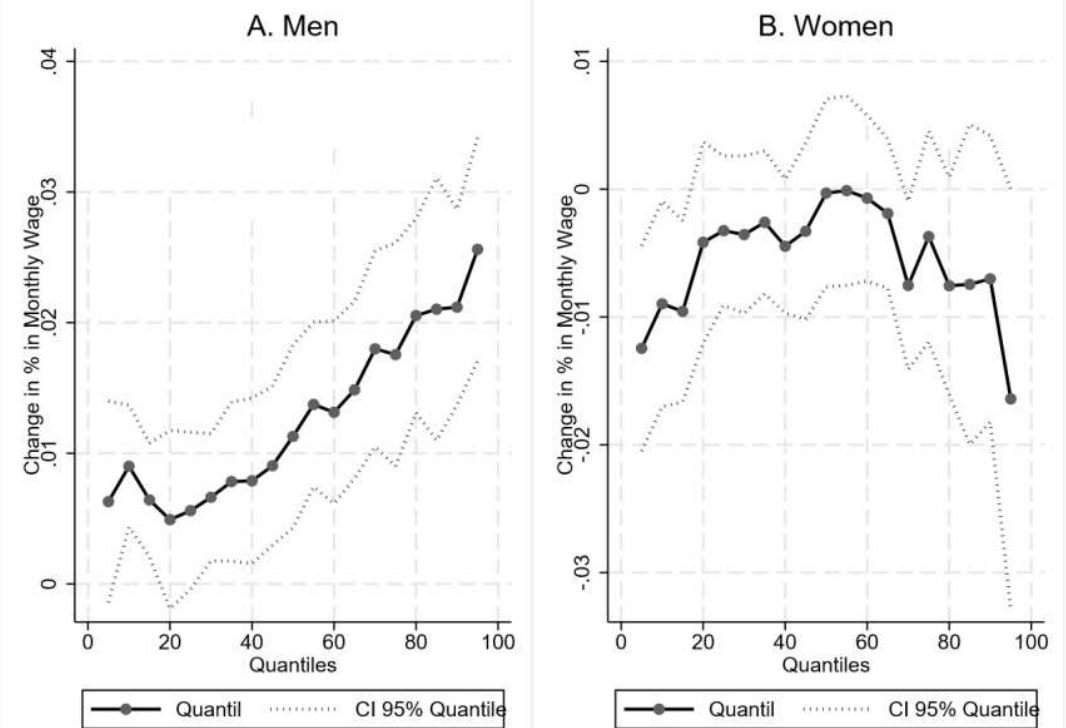

Notes: Author's calculations, using data from the ENAHO-CENAN 20072011. Robust standard errors in parentheses. Wages given in Peruvian soles from September 2019. ***p<0.01, **p<0.05, *p<0.1. Both regressions include the following variables: age, age squared, dummies of rural, geographic area, year of the survey, speaks an indigenous language, literacy, married, formal labor, studies in private or public school, variables of health problems, experience and experience squared. 


\section{Figure 6: Monthly wages in singled people}
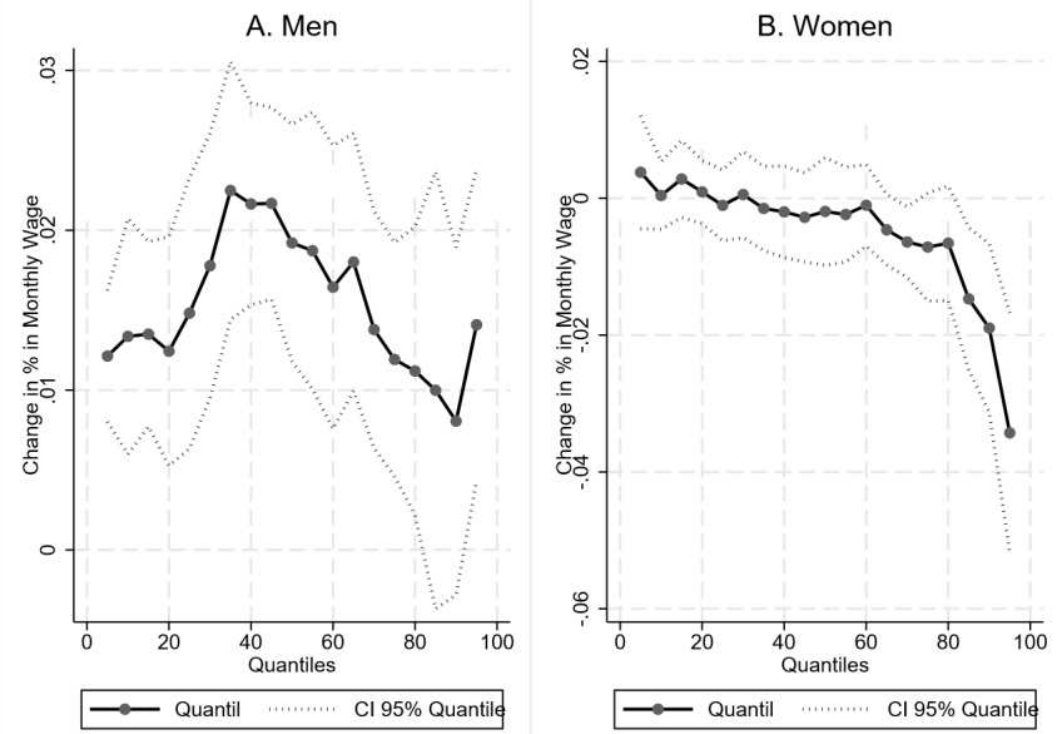

Notes: Author's calculations, using data from the ENAHO-CENAN 20072011. Robust standard errors in parentheses. Wages given in Peruvian soles from September 2019. ***p<0.01, **p<0.05, *p<0.1. Both regressions include the following variables: age, age squared, dummies of rural, geographic area, year of the survey, speaks an indigenous language, literacy, married, formal labor, studies in private or public school, variables of health problems, experience and experience squared. 
Figure 7: Monthly wages in rural areas
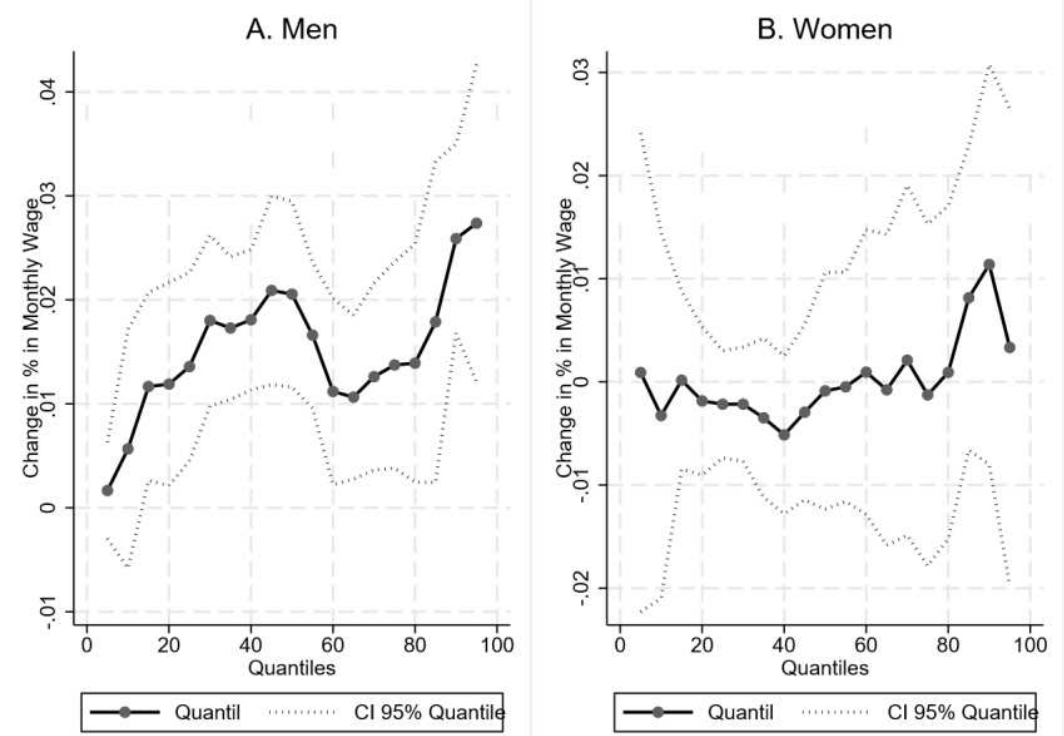

Notes: Author's calculations, using data from the ENAHO-CENAN 20072011. Robust standard errors in parentheses. Wages given in Peruvian soles from September 2019. ***p<0.01, **p<0.05, *p<0.1. Both regressions include the following variables: age, age squared, dummies of rural, geographic area, year of the survey, speaks an indigenous language, literacy, married, formal labor, studies in private or public school, variables of health problems, experience and experience squared. 


\section{Figure 8: Monthly wages in non-rural areas}
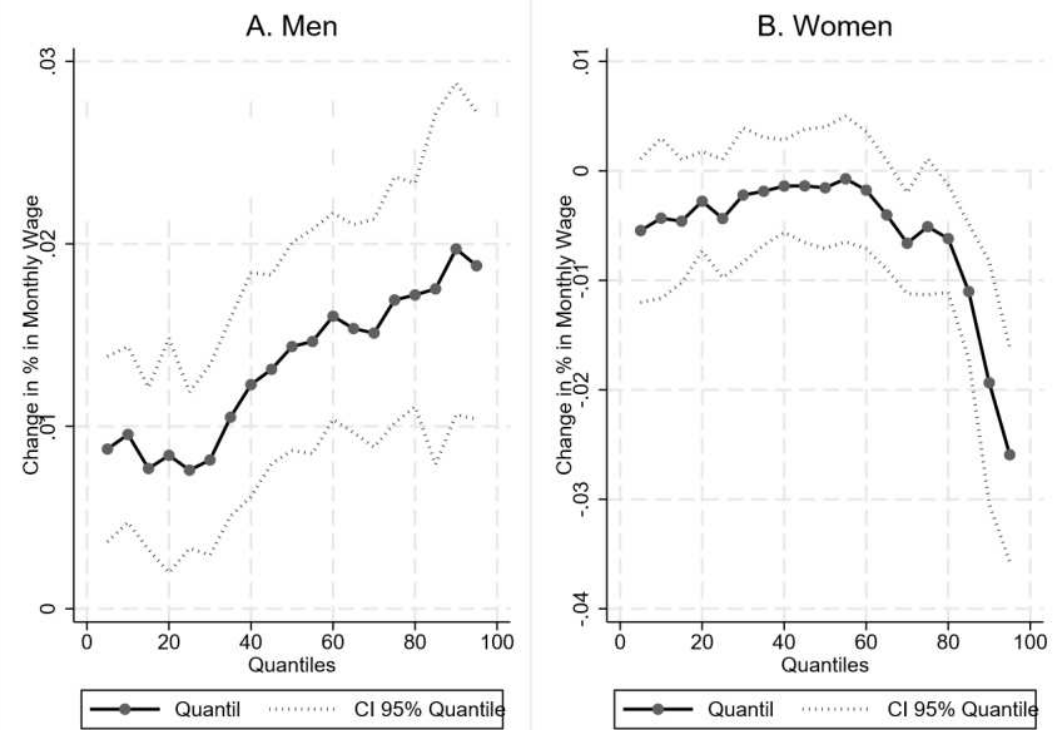

Notes: Author's calculations, using data from the ENAHO-CENAN 20072011. Robust standard errors in parentheses. Wages given in Peruvian soles from September 2019. ***p<0.01, **p<0.05, *p<0.1. Both regressions include the following variables: age, age squared, dummies of rural, geographic area, year of the survey, speaks an indigenous language, literacy, married, formal labor, studies in private or public school, variables of health problems, experience and experience squared. 


\section{Online appendix}

Table A1: Results on employment

\begin{tabular}{|c|c|c|}
\hline & Men & Women \\
\hline BMI & $\begin{array}{l}-0.002 \\
(0.001)\end{array}$ & $\begin{array}{c}-0.003 * * * \\
(0.001)\end{array}$ \\
\hline age & $\begin{array}{c}0.012 * * * \\
(0.002)\end{array}$ & $\begin{array}{c}0.008 * * * \\
(0.002)\end{array}$ \\
\hline age squared & $\begin{array}{c}-0.000 * * * \\
(0.000)\end{array}$ & $\begin{array}{c}-0.000 * * * \\
(0.000)\end{array}$ \\
\hline rural & $\begin{array}{c}-0.071 * * * \\
(0.010)\end{array}$ & $\begin{array}{c}-0.053 * * * \\
(0.008)\end{array}$ \\
\hline area1 & $\begin{array}{c}0.076 * * * \\
(0.016)\end{array}$ & $\begin{array}{c}-0.069 * * * \\
(0.018)\end{array}$ \\
\hline area2 & $\begin{array}{c}0.076 * * * \\
(0.019)\end{array}$ & $\begin{array}{c}-0.046^{* *} \\
(0.019)\end{array}$ \\
\hline area3 & $\begin{array}{c}0.068 * * * \\
(0.022)\end{array}$ & \\
\hline area5 & $\begin{array}{c}0.013 \\
(0.016)\end{array}$ & $\begin{array}{c}-0.071 * * * \\
(0.018)\end{array}$ \\
\hline area6 & $\begin{array}{c}0.009 \\
(0.017)\end{array}$ & $\begin{array}{c}-0.063 * * * \\
(0.019)\end{array}$ \\
\hline area7 & $\begin{array}{l}-0.009 \\
(0.014)\end{array}$ & $\begin{array}{c}-0.069 * * * \\
(0.018)\end{array}$ \\
\hline area8 & $\begin{array}{c}0.058 * * * \\
(0.017)\end{array}$ & $\begin{array}{c}0.027 \\
(0.019)\end{array}$ \\
\hline year1 & $\begin{array}{c}0.031 * * \\
(0.014)\end{array}$ & \\
\hline year3 & $\begin{array}{c}0.017 \\
(0.013)\end{array}$ & $\begin{array}{c}0.030 * * * \\
(0.010)\end{array}$ \\
\hline year4 & $\begin{array}{c}0.019 \\
(0.013)\end{array}$ & $\begin{array}{c}0.020 * * \\
(0.010)\end{array}$ \\
\hline year5 & $\begin{array}{c}0.024^{*} \\
(0.014)\end{array}$ & $\begin{array}{c}0.033 * * * \\
(0.011)\end{array}$ \\
\hline yschool & $\begin{array}{c}-0.003 * * \\
(0.001)\end{array}$ & $\begin{array}{c}0.005^{* * *} * \\
(0.001)\end{array}$ \\
\hline
\end{tabular}

Continued... 


\begin{tabular}{|c|c|c|}
\hline indig-lang & $\begin{array}{l}-0.003 \\
(0.012)\end{array}$ & $\begin{array}{c}-0.012 \\
(0.011)\end{array}$ \\
\hline literacy & $\begin{array}{c}0.002 \\
(0.013)\end{array}$ & $\begin{array}{c}0.004 \\
(0.009)\end{array}$ \\
\hline married & $\begin{array}{c}0.024 * * \\
(0.011)\end{array}$ & $\begin{array}{c}-0.091 * * * \\
(0.008)\end{array}$ \\
\hline experience & $\begin{array}{c}-0.002 * * * \\
(0.000)\end{array}$ & $\begin{array}{c}-0.001 * * * \\
(0.000)\end{array}$ \\
\hline experience2 & $\begin{array}{c}0.000 * * * \\
(0.000)\end{array}$ & $\begin{array}{c}0.000 * * * \\
(0.000)\end{array}$ \\
\hline formal & $\begin{array}{c}0.719 * * * \\
(0.008)\end{array}$ & $\begin{array}{c}0.795 * * * \\
(0.008)\end{array}$ \\
\hline priv-sch & $\begin{array}{l}-0.030 \\
(0.028)\end{array}$ & $\begin{array}{l}-0.017 \\
(0.027)\end{array}$ \\
\hline hipert & $\begin{array}{l}-0.016 \\
(0.011)\end{array}$ & $\begin{array}{c}-0.019 * * \\
(0.009)\end{array}$ \\
\hline diabet & $\begin{array}{l}-0.008 \\
(0.013)\end{array}$ & $\begin{array}{c}-0.001 \\
(0.012)\end{array}$ \\
\hline heart-dis & $\begin{array}{l}-0.009 \\
(0.012)\end{array}$ & $\begin{array}{c}-0.025 * * * \\
(0.009)\end{array}$ \\
\hline cancer & $\begin{array}{l}-0.012 \\
(0.013)\end{array}$ & $\begin{array}{c}0.009 \\
(0.012)\end{array}$ \\
\hline tobacco & $\begin{array}{l}-0.013 \\
(0.014)\end{array}$ & $\begin{array}{c}0.011 \\
(0.014)\end{array}$ \\
\hline alcohol & $\begin{array}{c}0.019 \\
(0.012)\end{array}$ & $\begin{array}{c}-0.015 \\
(0.010)\end{array}$ \\
\hline area4 & & $\begin{array}{c}-0.089 * * * \\
(0.020)\end{array}$ \\
\hline year2 & & $\begin{array}{l}-0.016 \\
(0.012)\end{array}$ \\
\hline $\mathrm{N}$ & 22,983 & 22,189 \\
\hline $\mathrm{R}-2$ adj. & 0.452 & 0.533 \\
\hline $\begin{array}{l}\text { Notes: Author } \\
\text { from the EN } \\
\text { Robust standa } \\
* * * \text { p }<0.01, * * 1\end{array}$ & $\begin{array}{l}\text { calculation } \\
\text { HO-CENAN } \\
\text { errors in } \\
0.05, * \mathrm{p}<0\end{array}$ & $\begin{array}{l}\text { using data } \\
\text { 2007-2011. } \\
\text { parentheses. }\end{array}$ \\
\hline
\end{tabular}


Table A2: Results on employment

\begin{tabular}{|c|c|c|}
\hline & Men & Women \\
\hline BMI & $\begin{array}{c}0.029 * * * \\
(0.010)\end{array}$ & $\begin{array}{c}0.003 \\
(0.007)\end{array}$ \\
\hline BMI squared & $\begin{array}{c}-0.001 * * * \\
(0.000)\end{array}$ & $\begin{array}{c}-0.000 \\
(0.000)\end{array}$ \\
\hline age & $\begin{array}{c}0.011 * * * \\
(0.002)\end{array}$ & $\begin{array}{c}0.007 * * * \\
(0.002)\end{array}$ \\
\hline age squared & $\begin{array}{c}-0.000 * * * \\
(0.000)\end{array}$ & $\begin{array}{c}-0.000 * * * \\
(0.000)\end{array}$ \\
\hline rural & $\begin{array}{c}-0.070 * * * \\
(0.010)\end{array}$ & $\begin{array}{c}-0.053 * * * \\
(0.008)\end{array}$ \\
\hline area1 & $\begin{array}{c}0.077 * * * \\
(0.016)\end{array}$ & $\begin{array}{c}-0.070 * * * \\
(0.018)\end{array}$ \\
\hline area2 & $\begin{array}{c}0.076 * * * \\
(0.019)\end{array}$ & $\begin{array}{c}-0.047 * * \\
(0.019)\end{array}$ \\
\hline area3 & $\begin{array}{c}0.069 * * * \\
(0.022)\end{array}$ & \\
\hline area5 & $\begin{array}{c}0.014 \\
(0.016)\end{array}$ & $\begin{array}{c}-0.071 * * * \\
(0.018)\end{array}$ \\
\hline area6 & $\begin{array}{c}0.010 \\
(0.017)\end{array}$ & $\begin{array}{c}-0.063 * * * \\
(0.019)\end{array}$ \\
\hline area7 & $\begin{array}{l}-0.009 \\
(0.014)\end{array}$ & $\begin{array}{c}-0.069 * * * \\
(0.018)\end{array}$ \\
\hline area8 & $\begin{array}{c}0.058 * * * \\
(0.017)\end{array}$ & $\begin{array}{c}0.027 \\
(0.019)\end{array}$ \\
\hline year1 & $\begin{array}{c}0.032 * * \\
(0.014)\end{array}$ & \\
\hline year3 & $\begin{array}{c}0.017 \\
(0.013)\end{array}$ & $\begin{array}{c}0.030 * * * \\
(0.010)\end{array}$ \\
\hline year4 & $\begin{array}{c}0.019 \\
(0.013)\end{array}$ & $\begin{array}{c}0.020 * * \\
(0.010)\end{array}$ \\
\hline year5 & $\begin{array}{c}0.023 \\
(0.014)\end{array}$ & $\begin{array}{c}0.033 * * * \\
(0.011)\end{array}$ \\
\hline yschool & $\begin{array}{c}-0.003 * * \\
(0.001)\end{array}$ & $\begin{array}{c}0.005^{* * *} * \\
(0.001)\end{array}$ \\
\hline
\end{tabular}

Continued... 


\begin{tabular}{|c|c|c|}
\hline indig-lang & $\begin{array}{l}-0.004 \\
(0.012)\end{array}$ & $\begin{array}{c}-0.012 \\
(0.011)\end{array}$ \\
\hline literacy & $\begin{array}{c}0.002 \\
(0.013)\end{array}$ & $\begin{array}{c}0.004 \\
(0.009)\end{array}$ \\
\hline married & $\begin{array}{c}0.022 * * \\
(0.011)\end{array}$ & $\begin{array}{c}-0.091 * * * \\
(0.008)\end{array}$ \\
\hline experience & $\begin{array}{c}-0.002 * * * \\
(0.000)\end{array}$ & $\begin{array}{c}-0.001 * * * \\
(0.000)\end{array}$ \\
\hline experience2 & $\begin{array}{c}0.000 * * * \\
(0.000)\end{array}$ & $\begin{array}{c}0.000 * * * \\
(0.000)\end{array}$ \\
\hline formal & $\begin{array}{c}0.718 * * * \\
(0.008)\end{array}$ & $\begin{array}{c}0.795 * * * \\
(0.008)\end{array}$ \\
\hline priv-sch & $\begin{array}{l}-0.030 \\
(0.028)\end{array}$ & $\begin{array}{l}-0.017 \\
(0.027)\end{array}$ \\
\hline hipert & $\begin{array}{l}-0.016 \\
(0.011)\end{array}$ & $\begin{array}{c}-0.019 * * \\
(0.009)\end{array}$ \\
\hline diabet & $\begin{array}{l}-0.008 \\
(0.013)\end{array}$ & $\begin{array}{l}-0.000 \\
(0.012)\end{array}$ \\
\hline heart-dis & $\begin{array}{l}-0.009 \\
(0.012)\end{array}$ & $\begin{array}{c}-0.025 * * * \\
(0.009)\end{array}$ \\
\hline cancer & $\begin{array}{l}-0.012 \\
(0.013)\end{array}$ & $\begin{array}{c}0.009 \\
(0.012)\end{array}$ \\
\hline tobacco & $\begin{array}{l}-0.013 \\
(0.014)\end{array}$ & $\begin{array}{c}0.011 \\
(0.014)\end{array}$ \\
\hline alcohol & $\begin{array}{c}0.018 \\
(0.012)\end{array}$ & $\begin{array}{c}-0.015 \\
(0.010)\end{array}$ \\
\hline area4 & & $\begin{array}{c}-0.090 * * * \\
(0.020)\end{array}$ \\
\hline year2 & & $\begin{array}{l}-0.016 \\
(0.012)\end{array}$ \\
\hline $\mathrm{N}$ & 22,983 & 22,189 \\
\hline $\mathrm{R}-2$ adj. & 0.453 & 0.533 \\
\hline $\begin{array}{l}\text { Notes: Author } \\
\text { from the EN } \\
\text { Robust standa } \\
* * * \text { p }<0.01, * * 1\end{array}$ & $\begin{array}{l}\text { calculation } \\
\text { HO-CENAN } \\
\text { errors in } \\
0.05, * \mathrm{p}<0\end{array}$ & $\begin{array}{l}\text { using data } \\
\text { 2007-2011. } \\
\text { parentheses. }\end{array}$ \\
\hline
\end{tabular}


Table A3: Results on employment

\begin{tabular}{|c|c|c|}
\hline & Men & Women \\
\hline \multirow[t]{2}{*}{ Overweight } & -0.003 & $-0.014^{*}$ \\
\hline & $(0.010)$ & $(0.008)$ \\
\hline \multirow[t]{2}{*}{ Obese } & $-0.049 * * *$ & $-0.043 * * *$ \\
\hline & $(0.013)$ & $(0.010)$ \\
\hline \multirow[t]{2}{*}{ age } & $0.012 * * *$ & $0.008 * * *$ \\
\hline & $(0.002)$ & $(0.002)$ \\
\hline \multirow[t]{2}{*}{ age squared } & $-0.000 * * *$ & $-0.000 * * *$ \\
\hline & $(0.000)$ & $(0.000)$ \\
\hline \multirow[t]{2}{*}{ rural } & $-0.072 * * *$ & $-0.054 * * *$ \\
\hline & $(0.010)$ & (0.008) \\
\hline \multirow[t]{2}{*}{ area1 } & $0.079 * * *$ & $-0.070 * * *$ \\
\hline & $(0.016)$ & $(0.018)$ \\
\hline \multirow[t]{2}{*}{ area2 } & $0.078 * * *$ & $-0.046^{* *}$ \\
\hline & $(0.019)$ & $(0.019)$ \\
\hline \multirow[t]{2}{*}{ area3 } & $0.071 * * *$ & \\
\hline & $(0.022)$ & \\
\hline \multirow[t]{2}{*}{ area5 } & 0.014 & $-0.071 * * *$ \\
\hline & $(0.016)$ & $(0.018)$ \\
\hline \multirow[t]{2}{*}{ area6 } & 0.010 & $-0.064 * * *$ \\
\hline & $(0.017)$ & $(0.018)$ \\
\hline \multirow[t]{2}{*}{ area7 } & -0.008 & $-0.069 * * *$ \\
\hline & $(0.014)$ & $(0.018)$ \\
\hline \multirow[t]{2}{*}{ area8 } & $0.059 * * *$ & 0.026 \\
\hline & $(0.017)$ & (0.019) \\
\hline \multirow[t]{2}{*}{ year1 } & $0.032 * *$ & \\
\hline & $(0.014)$ & \\
\hline \multirow[t]{2}{*}{ year3 } & 0.018 & $0.030 * * *$ \\
\hline & $(0.013)$ & $(0.010)$ \\
\hline \multirow[t]{2}{*}{ year4 } & 0.020 & $0.020 * *$ \\
\hline & $(0.013)$ & $(0.010)$ \\
\hline \multirow[t]{2}{*}{ year5 } & $0.025^{*}$ & $0.033 * * *$ \\
\hline & $(0.014)$ & $(0.011)$ \\
\hline \multirow[t]{2}{*}{ yschool } & $-0.002 * *$ & $0.005^{* * *}$ \\
\hline & $(0.001)$ & $(0.001)$ \\
\hline
\end{tabular}

Continued... 


\begin{tabular}{|c|c|c|}
\hline indig-lang & $\begin{array}{l}-0.004 \\
(0.012)\end{array}$ & $\begin{array}{l}-0.012 \\
(0.011)\end{array}$ \\
\hline literacy & $\begin{array}{c}0.003 \\
(0.013)\end{array}$ & $\begin{array}{c}0.003 \\
(0.009)\end{array}$ \\
\hline married & $\begin{array}{c}0.024 * * \\
(0.011)\end{array}$ & $\begin{array}{c}-0.091 * * * \\
(0.008)\end{array}$ \\
\hline experience & $\begin{array}{c}-0.002 * * * \\
(0.000)\end{array}$ & $\begin{array}{c}-0.001 * * * \\
(0.000)\end{array}$ \\
\hline experience2 & $\begin{array}{c}0.000 * * * \\
(0.000)\end{array}$ & $\begin{array}{c}0.000 * * * \\
(0.000)\end{array}$ \\
\hline formal & $\begin{array}{c}0.719 * * * \\
(0.008)\end{array}$ & $\begin{array}{c}0.795 * * * \\
(0.008)\end{array}$ \\
\hline priv_sch & $\begin{array}{l}-0.031 \\
(0.028)\end{array}$ & $\begin{array}{l}-0.017 \\
(0.027)\end{array}$ \\
\hline hipert & $\begin{array}{l}-0.016 \\
(0.011)\end{array}$ & $\begin{array}{c}-0.019 * * \\
(0.009)\end{array}$ \\
\hline diabet & $\begin{array}{l}-0.007 \\
(0.013)\end{array}$ & $\begin{array}{l}-0.000 \\
(0.012)\end{array}$ \\
\hline heart-dis & $\begin{array}{l}-0.009 \\
(0.012)\end{array}$ & $\begin{array}{c}-0.025 * * * \\
(0.009)\end{array}$ \\
\hline cancer & $\begin{array}{l}-0.011 \\
(0.013)\end{array}$ & $\begin{array}{c}0.009 \\
(0.012)\end{array}$ \\
\hline tobacco & $\begin{array}{l}-0.013 \\
(0.014)\end{array}$ & $\begin{array}{c}0.010 \\
(0.014)\end{array}$ \\
\hline alcohol & $\begin{array}{c}0.018 \\
(0.012)\end{array}$ & $\begin{array}{c}-0.015 \\
(0.010)\end{array}$ \\
\hline area4 & & $\begin{array}{c}-0.091 * * * \\
(0.020)\end{array}$ \\
\hline year2 & & $\begin{array}{l}-0.016 \\
(0.012)\end{array}$ \\
\hline $\mathrm{N}$ & 22,983 & 22,189 \\
\hline $\mathrm{R}-2$ adj. & 0.453 & 0.533 \\
\hline $\begin{array}{l}\text { Notes: Author } \\
\text { from the EN } \\
\text { Robust standa } \\
* * * \text { p }<0.01, * * 1\end{array}$ & $\begin{array}{l}\text { calculation } \\
\text { HO-CENAN } \\
\text { errors in } \\
0.05, * \mathrm{p}<0\end{array}$ & $\begin{array}{l}\text { using data } \\
\text { 2007-2011. } \\
\text { parentheses. }\end{array}$ \\
\hline
\end{tabular}


Table A4: Results on monthly wages

\begin{tabular}{|c|c|c|}
\hline & Men & Women \\
\hline BMI & $\begin{array}{c}0.013 * * * \\
(0.003)\end{array}$ & $\begin{array}{c}-0.008 * * * \\
(0.003)\end{array}$ \\
\hline age & $\begin{array}{c}0.033 * * * \\
(0.005)\end{array}$ & $\begin{array}{c}0.020 * * * \\
(0.006)\end{array}$ \\
\hline age squared & $\begin{array}{c}-0.000 * * * \\
(0.000)\end{array}$ & $\begin{array}{c}-0.000 * * * \\
(0.000)\end{array}$ \\
\hline rural & $\begin{array}{c}-0.067 * * * \\
(0.018)\end{array}$ & $\begin{array}{c}0.013 \\
(0.027)\end{array}$ \\
\hline area1 & $\begin{array}{c}-0.116^{* * * *} \\
(0.033)\end{array}$ & $\begin{array}{c}-0.180 * * * \\
(0.038)\end{array}$ \\
\hline area2 & $\begin{array}{c}-0.075^{* *} \\
(0.035)\end{array}$ & $\begin{array}{c}-0.198 * * * \\
(0.037)\end{array}$ \\
\hline area4 & $\begin{array}{l}-0.068 \\
(0.042)\end{array}$ & $\begin{array}{c}-0.142 * * \\
(0.065)\end{array}$ \\
\hline area5 & $\begin{array}{l}-0.043 \\
(0.032)\end{array}$ & $\begin{array}{c}-0.106 * * * \\
(0.037)\end{array}$ \\
\hline area6 & $\begin{array}{l}-0.004 \\
(0.034)\end{array}$ & $\begin{array}{c}-0.118 * * * \\
(0.038)\end{array}$ \\
\hline area7 & $\begin{array}{c}-0.066^{* *} \\
(0.031)\end{array}$ & $\begin{array}{c}-0.114 * * * \\
(0.036)\end{array}$ \\
\hline area8 & $\begin{array}{c}0.132 * * * \\
(0.033)\end{array}$ & $\begin{array}{c}0.009 \\
(0.035)\end{array}$ \\
\hline year1 & $\begin{array}{l}-0.017 \\
(0.029)\end{array}$ & \\
\hline year3 & $\begin{array}{c}0.026 \\
(0.028)\end{array}$ & $\begin{array}{l}-0.019 \\
(0.034)\end{array}$ \\
\hline year4 & $\begin{array}{c}0.026 \\
(0.029)\end{array}$ & $\begin{array}{c}-0.006 \\
(0.034)\end{array}$ \\
\hline year5 & $\begin{array}{c}0.045 \\
(0.031)\end{array}$ & $\begin{array}{c}0.022 \\
(0.037)\end{array}$ \\
\hline yschool & $\begin{array}{c}0.046^{* * * *} \\
(0.003)\end{array}$ & $\begin{array}{c}0.052 * * * \\
(0.004)\end{array}$ \\
\hline
\end{tabular}

Continued... 


\begin{tabular}{|c|c|c|}
\hline indig-lang & $\begin{array}{l}-0.033 \\
(0.023)\end{array}$ & $\begin{array}{l}-0.040 \\
(0.032)\end{array}$ \\
\hline literacy & $\begin{array}{c}0.169 * * * \\
(0.034)\end{array}$ & $\begin{array}{c}0.242 * * * \\
(0.053)\end{array}$ \\
\hline married & $\begin{array}{c}0.100 * * * \\
(0.022)\end{array}$ & $\begin{array}{c}0.010 \\
(0.023)\end{array}$ \\
\hline experience & $\begin{array}{l}-0.000 \\
(0.000)\end{array}$ & $\begin{array}{c}0.002 * * * \\
(0.000)\end{array}$ \\
\hline experience2 & $\begin{array}{c}0.000 * * \\
(0.000)\end{array}$ & $\begin{array}{c}-0.000 * * * \\
(0.000)\end{array}$ \\
\hline formal & $\begin{array}{c}0.426 * * * \\
(0.022)\end{array}$ & $\begin{array}{c}0.418 * * * \\
(0.028)\end{array}$ \\
\hline priv-sch & $\begin{array}{l}-0.024 \\
(0.056)\end{array}$ & $\begin{array}{c}0.009 \\
(0.041)\end{array}$ \\
\hline hipert & $\begin{array}{l}-0.004 \\
(0.023)\end{array}$ & $\begin{array}{l}-0.006 \\
(0.028)\end{array}$ \\
\hline diabet & $\begin{array}{l}0.047 * \\
(0.028)\end{array}$ & $\begin{array}{c}0.009 \\
(0.031)\end{array}$ \\
\hline heart-dis & $\begin{array}{c}0.018 \\
(0.028)\end{array}$ & $\begin{array}{c}0.014 \\
(0.032)\end{array}$ \\
\hline cancer & $\begin{array}{l}-0.020 \\
(0.028)\end{array}$ & $\begin{array}{c}0.004 \\
(0.028)\end{array}$ \\
\hline tobacco & $\begin{array}{c}0.036 \\
(0.030)\end{array}$ & $\begin{array}{c}0.010 \\
(0.040)\end{array}$ \\
\hline alcohol & $\begin{array}{l}-0.006 \\
(0.023)\end{array}$ & $\begin{array}{c}-0.045 * \\
(0.026)\end{array}$ \\
\hline year2 & & $\begin{array}{l}-0.041 \\
(0.042)\end{array}$ \\
\hline $\mathrm{N}$ & 8,596 & 4,818 \\
\hline R-2 adj. & 0.425 & 0.481 \\
\hline
\end{tabular}

Notes: Author's calculations, using data from the ENAHO-CENAN 2007-2011. Robust standard errors in parentheses. Wages given in Peruvian soles from September 2019. $* * * p<0.01, * * p<0.05$, *p $<0.1$. 
Table A5: Results on monthly wages

\begin{tabular}{|c|c|c|}
\hline & Men & Women \\
\hline \multirow[t]{2}{*}{ BMI } & 0.027 & -0.016 \\
\hline & $(0.023)$ & $(0.021)$ \\
\hline \multirow[t]{2}{*}{ BMI squared } & -0.000 & 0.000 \\
\hline & $(0.000)$ & $(0.000)$ \\
\hline \multirow[t]{2}{*}{ age } & $0.032 * * *$ & $0.020 * * *$ \\
\hline & $(0.005)$ & $(0.006)$ \\
\hline \multirow[t]{2}{*}{ age squared } & $-0.000 * * *$ & $-0.000 * * *$ \\
\hline & $(0.000)$ & $(0.000)$ \\
\hline \multirow[t]{2}{*}{ rural } & $-0.067 * * *$ & 0.013 \\
\hline & $(0.018)$ & $(0.027)$ \\
\hline \multirow[t]{2}{*}{ area1 } & $-0.116 * * *$ & $-0.179 * * *$ \\
\hline & $(0.033)$ & $(0.038)$ \\
\hline \multirow[t]{2}{*}{ area2 } & $-0.076 * *$ & $-0.197 * * *$ \\
\hline & $(0.035)$ & $(0.037)$ \\
\hline \multirow[t]{2}{*}{ area4 } & -0.069 & $-0.141 * *$ \\
\hline & $(0.042)$ & $(0.065)$ \\
\hline \multirow[t]{2}{*}{ area5 } & -0.043 & $-0.105 * * *$ \\
\hline & $(0.032)$ & $(0.037)$ \\
\hline \multirow[t]{2}{*}{ area6 } & -0.004 & $-0.117 * * *$ \\
\hline & $(0.034)$ & $(0.038)$ \\
\hline \multirow[t]{2}{*}{ area7 } & $-0.066 * *$ & $-0.113 * * *$ \\
\hline & $(0.031)$ & $(0.036)$ \\
\hline \multirow[t]{2}{*}{ area8 } & $0.132 * * *$ & 0.009 \\
\hline & $(0.033)$ & $(0.035)$ \\
\hline \multirow[t]{2}{*}{ year1 } & -0.017 & \\
\hline & $(0.029)$ & \\
\hline \multirow[t]{2}{*}{ year3 } & 0.026 & -0.019 \\
\hline & $(0.028)$ & $(0.034)$ \\
\hline \multirow[t]{2}{*}{ year4 } & 0.026 & -0.006 \\
\hline & (0.029) & $(0.034)$ \\
\hline \multirow[t]{2}{*}{ year5 } & 0.045 & 0.023 \\
\hline & $(0.031)$ & $(0.037)$ \\
\hline \multirow[t]{2}{*}{ yschool } & $0.046 * * *$ & $0.052 * * *$ \\
\hline & $(0.003)$ & $(0.004)$ \\
\hline
\end{tabular}

Continued... 


\begin{tabular}{|c|c|c|}
\hline indig-lang & $\begin{array}{l}-0.034 \\
(0.023)\end{array}$ & $\begin{array}{l}-0.040 \\
(0.032)\end{array}$ \\
\hline literacy & $\begin{array}{c}0.168 * * * \\
(0.034)\end{array}$ & $\begin{array}{c}0.242 * * * \\
(0.053)\end{array}$ \\
\hline married & $\begin{array}{c}0.099 * * * \\
(0.022)\end{array}$ & $\begin{array}{c}0.011 \\
(0.023)\end{array}$ \\
\hline experience & $\begin{array}{l}-0.000 \\
(0.000)\end{array}$ & $\begin{array}{c}0.002 * * * \\
(0.000)\end{array}$ \\
\hline experience2 & $\begin{array}{c}0.000 * * \\
(0.000)\end{array}$ & $\begin{array}{c}-0.000 * * * \\
(0.000)\end{array}$ \\
\hline formal & $\begin{array}{c}0.426 * * * \\
(0.022)\end{array}$ & $\begin{array}{c}0.418 * * * \\
(0.028)\end{array}$ \\
\hline priv-sch & $\begin{array}{l}-0.023 \\
(0.056)\end{array}$ & $\begin{array}{c}0.009 \\
(0.041)\end{array}$ \\
\hline hipert & $\begin{array}{l}-0.004 \\
(0.023)\end{array}$ & $\begin{array}{l}-0.006 \\
(0.028)\end{array}$ \\
\hline diabet & $\begin{array}{l}0.047 * \\
(0.028)\end{array}$ & $\begin{array}{c}0.009 \\
(0.031)\end{array}$ \\
\hline heart-dis & $\begin{array}{c}0.019 \\
(0.028)\end{array}$ & $\begin{array}{c}0.014 \\
(0.033)\end{array}$ \\
\hline cancer & $\begin{array}{l}-0.020 \\
(0.028)\end{array}$ & $\begin{array}{c}0.004 \\
(0.028)\end{array}$ \\
\hline tobacco & $\begin{array}{c}0.036 \\
(0.030)\end{array}$ & $\begin{array}{c}0.010 \\
(0.040)\end{array}$ \\
\hline alcohol & $\begin{array}{l}-0.007 \\
(0.023)\end{array}$ & $\begin{array}{c}-0.045 * \\
(0.026)\end{array}$ \\
\hline year2 & & $\begin{array}{l}-0.041 \\
(0.042)\end{array}$ \\
\hline $\mathrm{N}$ & 8,596 & 4,818 \\
\hline R-2 adj. & 0.425 & 0.481 \\
\hline
\end{tabular}

Notes: Author's calculations, using data from the ENAHO-CENAN 2007-2011. Robust standard errors in parentheses. Wages given in Peruvian soles from September 2019. $* * * p<0.01, * * p<0.05$, *p $<0.1$. 
Table A6: Results on monthly wages

\begin{tabular}{|c|c|c|}
\hline & Men & Women \\
\hline Overweight & $\begin{array}{l}0.039 * \\
(0.020)\end{array}$ & $\begin{array}{c}-0.049 * \\
(0.026)\end{array}$ \\
\hline Obese & $\begin{array}{c}0.119 * * * \\
(0.031)\end{array}$ & $\begin{array}{c}-0.094 * * * \\
(0.028)\end{array}$ \\
\hline age & $\begin{array}{c}0.035 * * * \\
(0.005)\end{array}$ & $\begin{array}{c}0.020 * * * \\
(0.006)\end{array}$ \\
\hline age squared & $\begin{array}{c}-0.000 * * * \\
(0.000)\end{array}$ & $\begin{array}{c}-0.000 * * * \\
(0.000)\end{array}$ \\
\hline rural & $\begin{array}{c}-0.069 * * * \\
(0.018)\end{array}$ & $\begin{array}{c}0.014 \\
(0.027)\end{array}$ \\
\hline area1 & $\begin{array}{c}-0.118 * * * \\
(0.033)\end{array}$ & $\begin{array}{c}-0.176 * * * \\
(0.038)\end{array}$ \\
\hline area2 & $\begin{array}{c}-0.075^{* *} \\
(0.035)\end{array}$ & $\begin{array}{c}-0.194 * * * \\
(0.037)\end{array}$ \\
\hline area4 & $\begin{array}{l}-0.071 * \\
(0.042)\end{array}$ & $\begin{array}{c}-0.138 * * \\
(0.066)\end{array}$ \\
\hline area5 & $\begin{array}{c}-0.048 \\
(0.032)\end{array}$ & $\begin{array}{c}-0.103 * * * \\
(0.037)\end{array}$ \\
\hline area6 & $\begin{array}{l}-0.008 \\
(0.034)\end{array}$ & $\begin{array}{c}-0.116 * * * \\
(0.038)\end{array}$ \\
\hline area7 & $\begin{array}{c}-0.069 * * \\
(0.031)\end{array}$ & $\begin{array}{c}-0.110 * * * \\
(0.036)\end{array}$ \\
\hline area8 & $\begin{array}{c}0.133 * * * \\
(0.033)\end{array}$ & $\begin{array}{c}0.011 \\
(0.035)\end{array}$ \\
\hline year1 & $\begin{array}{l}-0.018 \\
(0.029)\end{array}$ & \\
\hline year3 & $\begin{array}{c}0.026 \\
(0.028)\end{array}$ & $\begin{array}{l}-0.019 \\
(0.034)\end{array}$ \\
\hline year4 & $\begin{array}{c}0.026 \\
(0.029)\end{array}$ & $\begin{array}{l}-0.006 \\
(0.034)\end{array}$ \\
\hline year5 & $\begin{array}{c}0.046 \\
(0.031)\end{array}$ & $\begin{array}{c}0.023 \\
(0.037)\end{array}$ \\
\hline yschool & $\begin{array}{c}0.046^{* * * *} \\
(0.003)\end{array}$ & $\begin{array}{c}0.052 * * * \\
(0.004)\end{array}$ \\
\hline
\end{tabular}

Continued... 


\begin{tabular}{|c|c|c|}
\hline indig-lang & $\begin{array}{l}-0.036 \\
(0.023)\end{array}$ & $\begin{array}{l}-0.037 \\
(0.032)\end{array}$ \\
\hline literacy & $\begin{array}{c}0.169 * * * \\
(0.034)\end{array}$ & $\begin{array}{c}0.241 * * * \\
(0.053)\end{array}$ \\
\hline married & $\begin{array}{c}0.102 * * * \\
(0.022)\end{array}$ & $\begin{array}{c}0.009 \\
(0.023)\end{array}$ \\
\hline experience & $\begin{array}{l}-0.000 \\
(0.000)\end{array}$ & $\begin{array}{c}0.002 * * * \\
(0.000)\end{array}$ \\
\hline experience2 & $\begin{array}{c}0.000 * * \\
(0.000)\end{array}$ & $\begin{array}{c}-0.000 * * * \\
(0.000)\end{array}$ \\
\hline formal & $\begin{array}{c}0.428 * * * \\
(0.022)\end{array}$ & $\begin{array}{c}0.420 * * * \\
(0.028)\end{array}$ \\
\hline priv-sch & $\begin{array}{l}-0.026 \\
(0.055)\end{array}$ & $\begin{array}{c}0.007 \\
(0.041)\end{array}$ \\
\hline hipert & $\begin{array}{l}-0.004 \\
(0.023)\end{array}$ & $\begin{array}{l}-0.009 \\
(0.028)\end{array}$ \\
\hline diabet & $\begin{array}{l}0.052^{*} \\
(0.028)\end{array}$ & $\begin{array}{c}0.011 \\
(0.031)\end{array}$ \\
\hline heart-dis & $\begin{array}{c}0.017 \\
(0.028)\end{array}$ & $\begin{array}{c}0.015 \\
(0.032)\end{array}$ \\
\hline cancer & $\begin{array}{l}-0.021 \\
(0.028)\end{array}$ & $\begin{array}{c}0.005 \\
(0.028)\end{array}$ \\
\hline tobacco & $\begin{array}{c}0.034 \\
(0.030)\end{array}$ & $\begin{array}{c}0.009 \\
(0.040)\end{array}$ \\
\hline alcohol & $\begin{array}{l}-0.006 \\
(0.023)\end{array}$ & $\begin{array}{c}-0.046 * \\
(0.026)\end{array}$ \\
\hline year2 & & $\begin{array}{l}-0.042 \\
(0.042)\end{array}$ \\
\hline $\mathrm{N}$ & 8,596 & 4,818 \\
\hline R-2 adj. & 0.423 & 0.481 \\
\hline
\end{tabular}

Notes: Author's calculations, using data from the ENAHO-CENAN 2007-2011. Robust standard errors in parentheses. Wages given in Peruvian soles from September 2019. $* * * p<0.01, * * p<0.05$, *p $<0.1$. 